\title{
The equilibrium response to idealized thermal forcings in a comprehensive GCM: implications for recent tropical expansion
}

\author{
R. J. Allen ${ }^{1,2,3}$, S. C. Sherwood ${ }^{4}$, J. R. Norris ${ }^{2}$, and C. S. Zender ${ }^{3}$ \\ ${ }^{1}$ Department of Earth Sciences, University of California, Riverside, Riverside, CA, USA \\ ${ }^{2}$ Scripps Institution of Oceanography, University of California, San Diego, CA, USA \\ ${ }^{3}$ Department of Earth System Science, University of California, Irvine, CA, USA \\ ${ }^{4}$ Climate Change Research Centre and ARC Centre of Excellence, University of New South Wales, Sydney, Australia
}

Correspondence to: R. J. Allen (rjallen@ucr.edu)

Received: 17 August 2011 - Published in Atmos. Chem. Phys. Discuss.: 2 December 2011

Revised: 22 March 2012 - Accepted: 11 May 2012 - Published: 31 May 2012

\begin{abstract}
Several recent studies have shown the width of the tropical belt has increased over the last several decades. The mechanisms driving tropical expansion are not well known and the recent expansion is underpredicted by state-of-the art GCMs. We use the CAM3 GCM to investigate how tropical width responds to idealized atmospheric heat sources, focusing on zonal displacement of the tropospheric jets. The heat sources include global and zonally restricted lowertropospheric warmings and stratospheric coolings, which coarsely represent possible impacts of ozone or aerosol changes. Similar to prior studies with simplified GCMs, we find that stratospheric cooling - particularly at high-latitudes - shifts jets poleward and excites Northern and Southern Annular Mode (NAM/SAM)-type responses. We also find, however, that modest heating of the midlatitude boundary layer drives a similar response; heating at high latitudes provokes a weaker, equatorward shift and tropical heating produces no shift. Over $70 \%$ of the variance in annual mean jet displacements across 27 experiments is accounted for by a newly proposed "Expansion Index", which compares mid-latitude tropospheric warming to that at other latitudes. We find that previously proposed factors, including tropopause height and tropospheric stability, do not fully explain the results. Results suggest recently observed tropical expansion could have been driven not only by stratospheric cooling, but also by mid-latitude heating sources due for example to ozone or aerosol changes.
\end{abstract}

\section{Introduction}

Recent observational analyses show the tropics have widened over the last several decades. Estimates range from $2-5^{\circ}$ latitude since 1979 (Seidel et al., 2008) and are based on several metrics, including a poleward shift of the Hadley cell $(\mathrm{Hu}$ and $\mathrm{Fu}, 2007$ ), increased frequency of high tropopause days in the subtropics (Seidel and Randel, 2007) and increased width of the region with tropical column ozone levels (Hudson et al., 2006). Studies have also inferred a poleward shift in the tropospheric jets, based on enhanced warming in the mid-latitude troposphere (Fu et al., 2006) and cooling in the mid-latitude stratosphere (Fu and Lin, 2011). Zhou et al. (2011) showed a poleward shift of cloud boundaries associated with the Hadley cell, as well as a poleward shift of the subtropical dry zones. Clearly, tropical expansion has important implications for both global, and regional climate.

Climate models also show current, and future, global warming is associated with tropical expansion. Using the Intergovernmental Panel on Climate Change (IPCC) Coupled Model Intercomparison Project, Phase 3 (CMIP3) simulations, Yin (2005) found a poleward shift in the mid-latitude storm tracks, which was accompanied by poleward shifts in surface wind stress and precipitation. Similarly, Lorenz and DeWeaver (2007) found a poleward shift (and strengthening) of the tropospheric jets in response to global warming, which was accompanied by poleward and upward shifts in transient kinetic energy and momentum flux. Lu et al. (2007) showed CMIP3 models yield poleward displacement (and weakening) of the Hadley cell and subtropical dry zones, which 
is associated with an increase in extratropical tropopause height, and subtropical static stability. Models also show that tropical expansion projects onto the leading pattern of variability (Kushner et al., 2001), with about half of CMIP3 model-simulated Hadley cell and subtropical dry zone expansion during the next century explained by positive trends in the Northern and Southern Annular Mode (NAM/SAM) (Previdi and Liepert, 2007).

Although both GCMs and observations show tropical widening over the last 2-3 decades, models underestimate the magnitude of observed trends. For example, Johanson and Fu (2009) show the largest CMIP3 tropical widening trends are $\sim 1 / 5$ of the observed widening. This significant underestimation exists across five scenarios, as well as three separate definitions of Hadley cell width, including dynamical and hydrological definitions. Lu et al. (2009) used the GFDL atmospheric model AM2.1 to show observed changes in sea surface temperatures (SSTs) and sea-ice cannot explain increased tropical width, as defined by the tropopause probability density function. A similar simulation, however, that also included the direct radiative effects of anthropogenic and natural sources better reproduced the observed widening. Polvani et al. (2011) showed that broadening of the Hadley cell and poleward expansion of the subtropical dry zone over the latter half of the 20th century in the $\mathrm{SH}-$ particularly during December-January-February - have been primarily caused by polar stratospheric ozone depletion.

Idealized climate models (e.g., no moist processes, no topography) have been used to better understand the mechanisms involved with tropical expansion. Polvani and Kushner (2002) and Kushner and Polvani (2004) found that cooling of the polar winter stratosphere, which is associated with reduced stratospheric wave drag, results in a poleward tropospheric jet shift and strengthening of surface wind. Haigh et al. (2005) showed that uniform heating of the stratosphere (e.g., via increased solar or volcanic activity), or heating restricted to high-latitudes, forces the jets equatorward; heating in low latitudes forces them poleward.

Frierson et al. (2007) used both simple and comprehensive GCMs to show tropical expansion occurs with increased global mean temperature, and secondly, with an increased pole-to-equator temperature gradient. They argued that the response was due to increased static stability, which reduces baroclinic growth rates and pushes the latitude of baroclinic instability onset poleward, in agreement with the Hadley cell width scaling of Held (2000). This was further supported by $\mathrm{Lu}$ et al. (2008), who showed that poleward expansion of the Hadley cell and shift of the eddy-driven jet in CMIP3 global warming experiments are related to a reduction in baroclinicity, which is primarily caused by an increase in subtropical static stability. This relationship was most significant during austral summer (December-January-February), particularly in the Southern Hemisphere (SH).
Lorenz and DeWeaver (2007) showed that increasing the tropopause height (as expected in a warmer troposphere) in a simple dry GCM resulted in poleward jet displacement. This response was largest when the tropopause on the poleward flank of the jet was raised; however, the opposite response occurred if the tropopause was raised on the equatorward side of the jet. This tropopause-jet relationship is consistent with Williams (2006).

Recently, Butler et al. (2010) used a simplified GCM to try to attribute storm track shifts to temperature changes in particular regions. They found that warming in the tropical troposphere, or cooling in the high-latitude stratosphere, each shifted the storm tracks poleward, whereas polar surface warming shifted them equatorward. Such results are qualitatively consistent with earlier studies (Chen and Held, 2007; Chen et al., 2008), arguing that the observed poleward shift in the surface westerlies has been due to increased Rossby wave phase speeds, which results in poleward displacement of the region of wave breaking in the subtropics. Kidston et al. (2011) argued that an increase in eddy length scale, a robust response to global warming (Kidston et al., 2010), causes the poleward shift of the mid-latitude eddy-driven jet streams. Both Brayshaw et al. (2008) and Chen et al. (2010) used aquaplanet GCM simulations to show that high-latitude SST warming poleward of the climatological jet results in an equatorward jet displacement. For low-latitude warming that extends poleward of the climatological jet latitude, a poleward jet displacement occurred.

Expanding upon these studies, we use a comprehensive GCM to gain a better understanding of how tropical width - particularly tropospheric $(850-300 \mathrm{hPa})$ jet displacement - responds to different types of simple heating at realistic amplitudes. The thermal forcings examined include zonally uniform heat sources in the troposphere or heat sinks in the stratosphere. Our study differs from past studies in specifying heat sources that are representative of possible non- $\mathrm{CO}_{2}$ climatic forcings, rather than imposing characteristic temperature perturbations. Investigation of the effects of such heat sources on tropical width is of interest due to the significant 20th century increases in anthropogenic aerosols, including absorbing aerosols like black carbon (Bond et al., 2007) and reflecting aerosols like sulfate (Smith et al., 2011), as well as tropospheric ozone (Shindell et al., 2006) and ozone precursors (van Aardenne et al., 2001). Our objective is to clarify the sensitivity of tropical width to different types of heating, with the ultimate goals of gaining insight into the observed widening and better understanding of the responses seen in past GCM studies. Our results show the importance of perturbed tropospheric temperature gradients and a wavemodulated stratospheric pathway in driving zonal jet displacements. We also show that previously proposed tropical expansion mechanisms are unable to fully explain our results. We build upon these results in a subsequent paper, which will examine the responses to more realistic representations of non- $\mathrm{CO}_{2}$ forcings. This paper is organized as follows: in 
Sect. 2 we discuss the CAM GCM and our experimental design. In Sect. 3 we present the response to idealized stratospheric cooling and tropospheric heating, and compare these responses to a doubling of $\mathrm{CO}_{2}$. Section 4 discusses expansion scenarios, including the tropospheric and stratospheric pathways. Conclusions are presented in Sect. 5.

\section{Methods}

\subsection{CAM description}

The Community Atmosphere Model (CAM) version 3 (Collins et al., 2004), is the fifth generation of the National Center for Atmosphere Research (NCAR) atmospheric General Circulation Model (GCM) and is the atmospheric component of the Community Climate System Model (CCSM). CAM uses a Eulerian spectral transform dynamical core, where variables are represented in terms of coefficients of a truncated series of spherical harmonic functions. The model time step is $20-\mathrm{min}$, and time integration is performed with a semi-implicit leapfrog scheme. The vertical coordinate is a hybrid coordinate, with 26 vertical levels. The model has a relatively poorly-resolved stratosphere, with $\sim 9$ levels above $100 \mathrm{hPa}$ and a top level at $2.9 \mathrm{hPa}$. The total parameterization package consists of four basic components: moist precipitation processes/convection, clouds and radiation, surface processes, and turbulent mixing. The land surface model is the Community Land Model (CLM) version 3 (Oleson et al., 2004), which combines realistic radiative, ecological and hydrologic processes.

\subsection{Experimental design}

CAM is run at T42 resolution $\left(\sim 2.8 \times 2.8^{\circ}\right)$ with a slab ocean-thermodynamic sea ice model. All experiments are run for at least $70 \mathrm{yr}$, the last 30 of which are used in this analysis, during which the model has reached equilibrium (i.e., no significant trend in TOA net energy flux).

Stratospheric cooling experiments (10PLO3; see Table 1) were performed by reducing the stratospheric ozone by $10 \%$ globally, as well as individually for the tropics $\left( \pm 30^{\circ}\right)$, mid-latitudes $\left(30-60^{\circ} \mathrm{N} / \mathrm{S}\right)$ and high-latitudes $\left(60-90^{\circ} \mathrm{N} / \mathrm{S}\right)$. The stratosphere is defined as the model levels above the tropopause, which is estimated by a thermal definition using the method of Reichler et al. (2003). We use CAM's default ozone boundary data set, which contains zonal monthly ozone volume mixing ratios, and reduce the ozone by $10 \%$ at the appropriate latitudes and stratospheric pressures on a monthly basis. A $10 \%$ ozone reduction is in rough agreement with the change in stratospheric ozone from 1979-2000 (Newchurch et al., 2003). The ozone perturbation is seasonally invariant, as are all perturbations in this study, and is not meant to represent the real seasonal cycle of ozone change.

Our standard set of tropospheric heating experiments (LTHT) adds a $0.1 \mathrm{~K} \mathrm{day}^{-1}\left(\sim 3.5 \mathrm{~W} \mathrm{~m}^{-2}\right)$ heating source to the lower troposphere (surface to $\sim 700 \mathrm{hPa}$ ). Such a heating rate is comparable to recent satellite-based estimates of present-day anthropogenic aerosol solar absorption (Chung et al., 2005). We conduct a globally uniform heating experiment, as well as latitudinally restricted heating of the tropics, mid- and high-latitudes. Although heating is only applied to the lower troposphere, the globally uniform temperature response resembles that based on a doubling of $\mathrm{CO}_{2}$. This is due to destabilization of the lower atmosphere and increased convection, which vertically redistributes the heat throughout the depth of the troposphere. Similar experiments with midtropospheric and upper-tropospheric heating do not destabilize the lower atmosphere, and result in maximum tropospheric warming near the altitude of heat input. Table 2 lists the suite of tropospheric heating experiments. In all cases, the response is estimated as the difference between the experiment and a corresponding control, which lacks the added heat source.

A standard global warming experiment is also performed, where the $\mathrm{CO}_{2}$ volume mixing ratio is doubled from $3.55 \times$ $10^{-4}$ to $7.10 \times 10^{-4}$. We also conduct an extreme global warming experiment, where the $\mathrm{CO}_{2}$ volume mixing ratio is increased by a factor of eight. The resulting climate signals are named $2 \times \mathrm{CO} 2$ and $8 \times \mathrm{CO} 2$, respectively.

We compare our CAM integrations to $122 \times \mathrm{CO} 2 \mathrm{CMIP} 3$ equilibrium (slab ocean) experiments, as well as $101 \%$ to $4 \times \mathrm{CO} 2$ transient CMIP3 experiments. Table 3 lists the CMIP3 models used in this study. For the $1 \%$ to $4 \times \mathrm{CO} 2 \mathrm{ex}-$ periments, we compare the $25 \mathrm{yr}$ prior to $\mathrm{CO}_{2}$ quadrupling (years 115-139) to the corresponding control.

Finally, we evaluate the robustness of some of our CAM results - specifically the response to lower tropospheric heating - using an alternate GCM, the GFDL AM2.1 (Anderson et al., 2004). Because the GFDL model does not include a slab ocean model, these experiments are run with climatological SSTs. GFDL experiments are integrated for $40 \mathrm{yr}$, the last 30 of which are used to estimate the climate response.

\subsection{Measures of tropical width and its changes}

\subsubsection{Tropospheric jet}

Several jet-based measures of tropical width were explored. This includes the latitude of the main jet, which we locate by finding the maximum of the zonally and monthly averaged zonal wind $(U)$ in either hemisphere ( $\mathrm{NH}$ or $\mathrm{SH})$. The poleward jet displacements are then estimated by taking the difference of the mean jet location (experiment minus control) in either hemisphere. We computed this measure on each pressure level and averaged the $850-300 \mathrm{hPa}$ displacements to obtain a tropospheric jet displacement. Because our jet definition is based on the entire troposphere, it primarily represents the subtropical jet, and secondarily the mid-latitude eddy-driven jet. Displacements of the tropospheric and eddy-driven jet, however, are closely related; 
Table 1. Stratospheric cooling experiments.

\begin{tabular}{ll}
\hline Signal & Description \\
\hline $10 \mathrm{PLO} 3$ & Global $10 \%$ reduction in stratospheric ozone \\
$10 \mathrm{PLO} 3 \mathrm{TR}$ & As 10PLO3, but ozone reduced over tropics $\left( \pm 30^{\circ}\right)$ only \\
$10 \mathrm{PLO} 3_{\mathrm{ML}}$ & As 10PLO3, but ozone reduced over mid-latitudes $\left(30-60^{\circ} \mathrm{N} / \mathrm{S}\right)$ \\
$10 \mathrm{PLO} 3_{\mathrm{HL}}$ & As 10PLO3, but ozone reduced over high-latitudes $\left(60-90^{\circ} \mathrm{N} / \mathrm{S}\right)$ \\
\hline
\end{tabular}

Table 2. Tropospheric heating experiments.

\begin{tabular}{|c|c|}
\hline Signal & Description \\
\hline LTHT & Global lower-tropospheric (surface to $\sim 700 \mathrm{hPa}$ ) heating of $0.1 \mathrm{~K} \mathrm{day}^{-1}$ \\
\hline LTHT $_{\mathrm{TR}}$ & As LTHT, but heating of tropics $\left( \pm 30^{\circ}\right)$ only \\
\hline $\mathrm{LTHT}_{\mathrm{ML}}$ & As LTHT, but heating of mid-latitudes $\left(30-60^{\circ} \mathrm{N} / \mathrm{S}\right)$ \\
\hline $\mathrm{LTHT}_{\mathrm{HL}}$ & As LTHT, but heating of high-latitudes $\left(60-90^{\circ} \mathrm{N} / \mathrm{S}\right)$ \\
\hline $\mathrm{LTHT}_{\mathrm{TRML}}$ & As LTHT, but heating of tropics and mid-latitudes $\left( \pm 60^{\circ}\right)$ \\
\hline LTHT MLHL $_{\text {ML }}$ & As LTHT, but heating of mid- and high-latitudes $\left( \pm 30-90^{\circ}\right)$ \\
\hline LTHT2x & As LTHT, but double the heating rate $\left(0.2 \mathrm{~K} \mathrm{day}^{-1}\right)$ \\
\hline LTHT4x & As LTHT, but quadruple the heating rate $\left(0.4 \mathrm{~K} \mathrm{day}^{-1}\right)$ \\
\hline MTHT & Heating the mid-troposphere $(\sim 700-400 \mathrm{hPa})$ \\
\hline $\mathrm{UTHT}_{\mathrm{ML}}$ & Mid-latitude heating of the upper troposphere (4 levels below tropopause) \\
\hline LTHT $_{10 \mathrm{PLO} 3}$ & Global lower-tropospheric heating of $0.1 \mathrm{~K} \mathrm{day}^{-1}$ and $10 \%$ reduction in stratospheric ozone \\
\hline
\end{tabular}

Table 3. Definition of the CMIP3 $2 \times \mathrm{CO} 2$ equilibrium (slab ocean) and the $1 \%$ to $4 \times \mathrm{CO} 2$ transient experiments used in this study. A "Y" ("N") indicates this model was (was not) used for the given experiment.

\begin{tabular}{llcc}
\hline Model Acronym & Institution & $2 \times \mathrm{CO} 2$ & $4 \times \mathrm{CO} 2$ \\
\hline CCSM3 & National Center for Atmospheric Research & $\mathrm{Y}$ & $\mathrm{Y}$ \\
CGCM3.1(T47) & Canadian Center for Climate Modeling and Analysis & $\mathrm{Y}$ & $\mathrm{Y}$ \\
CGCM3.1(T63) & Canadian Center for Climate Modeling and Analysis & $\mathrm{Y}$ & $\mathrm{N}$ \\
CSIRO-Mk3.0 & CSIRO Atmospheric Research & $\mathrm{Y}$ & $\mathrm{N}$ \\
ECHAM5/MPI-OM & Max Plank Institute for Meteorology & $\mathrm{Y}$ & $\mathrm{N}$ \\
GFDL-CM2.0 & Geophysical Fluid Dynamics Laboratory & $\mathrm{Y}$ & $\mathrm{Y}$ \\
GFDL-CM2.1 & Geophysical Fluid Dynamics Laboratory & $\mathrm{N}$ & $\mathrm{Y}$ \\
GISS-ER & Goddard Institute for Space Studies & $\mathrm{Y}$ & $\mathrm{Y}$ \\
INM-CM3.0 & Institute for Numerical Mathematics & $\mathrm{Y}$ & $\mathrm{Y}$ \\
IPSL-CM4 & Institut Pierre Simon Laplace & $\mathrm{N}$ & $\mathrm{Y}$ \\
MIROC3.2(hires) & Center for Climate System Research/NIES $/ J A M S T E C ~$ & $\mathrm{Y}$ & $\mathrm{N}$ \\
MIROC3.2(medres) & Center for Climate System Research/NIES /JAMSTEC & $\mathrm{Y}$ & $\mathrm{Y}$ \\
MRI-CGCM2.3.2 & Meteorological Research Institute & $\mathrm{Y}$ & $\mathrm{Y}$ \\
PCM & National Center for Atmospheric Research & $\mathrm{N}$ & $\mathrm{Y}$ \\
UKMO-HadGEM1 & Hadley Center for Climate Prediction and Research & $\mathrm{Y}$ & $\mathrm{N}$ \\
\hline
\end{tabular}

a NIES is the National Institute for Environmental Studies.

b JAMSTEC is the Frontier Research Center for Global Change in Japan.

the correlation between $2 \times \mathrm{CO} 2 \mathrm{CMIP} 3$ jet displacements using the annual mean $850-300 \mathrm{hPa} U$ maximum and the near-surface (10-m) $U$ maximum - which others have used as a measure of the eddy-driven jet (e.g., Kidston and Gerber, 2010 ) - is 0.83 in the $\mathrm{NH}$ and 0.90 in the $\mathrm{SH}$. The correlation is weakest during JJA in the $\mathrm{SH}(r=0.57)$, which is consistent with a winter-time decoupling of the subtropical and eddy jets, resulting in a double jet structure (e.g., Gallego et al., 2005).

We also investigated an additional method for locating the jet, where we located the "sides" of the jet and then found their midpoint; the sides were based on a specified percentile value of zonal wind. Although both methods yielded similar displacements, testing indicated that the percentile method yielded somewhat more stable results; thus only the results 
from the percentile method, using the 75th percentile (p75), are shown. We do note, however, that the percentile method yields smaller displacements than the maximum method, and as the percentile is decreased (e.g., from 95 to 70), consistently smaller jet displacements are obtained. This is illustrated in Fig. 1, which compares tropospheric jet displacements in 12 CMIP3 $2 \times \mathrm{CO} 2$ equilibrium experiments using the maximum method, and the percentile method (with p75). A correlation of 0.95 shows both methods yields similar displacements; however, displacements tend to be larger with the jet maximum approach. The ensemble annual mean jet displacement using the maximum method is $0.62^{\circ}$ in the $\mathrm{NH}$ and $0.96^{\circ}$ in the $\mathrm{SH}$; corresponding values using p75 are $0.46^{\circ}$ and $0.73^{\circ}$. This result shows the jet displacement is non-uniform.

Figure 1 also shows the CMIP3 $4 \times \mathrm{CO} 2$ ensemble annual zonal mean tropospheric jet response, and the corresponding control. The response is not a uniform jet shift; there is some distortion of its shape, resulting in a poleward skew, which is larger for the faster winds. This is particularly evident in the $\mathrm{SH}$, and helps to explain the larger poleward displacements with the jet maximum method. Similar, but weaker results exist for the $2 \times \mathrm{CO} 2$ equilibrium experiments (not shown).

\subsubsection{Other measures}

Additional measures of tropical displacement (Johanson and $\mathrm{Fu}, 2009$ ) include (1) the latitude of the subtropical Mean Meridional Circulation (MMC) minima, defined as the latitudes where the MMC at $500 \mathrm{hPa}$ becomes zero poleward of the subtropical maxima; and (2) the latitudes where precipitation minus evaporation $(P-E)$ becomes zero on the poleward side of the subtropical minima (a measure of subtropical dry zone expansion). All displacements are estimated by first smoothing the zonal monthly mean of the appropriate model field(s) and interpolating to $0.5^{\circ}$ resolution using cubic splines. Smoothing was performed by taking a running mean over $\sim 10$ degrees of latitude. Nearly identical results are obtained without interpolating.

In addition to zonal displacements, we also quantify the changes in the strength and altitude of the jet. The altitude of the jet was quantified by interpolating the zonal wind to $10 \mathrm{hPa}$ vertical resolution, and locating the pressure of maximum monthly zonal wind. This procedure is only done poleward of $\sim 20^{\circ}$, since the jet is not well defined in the tropics. The strength of the jet was quantified by locating the maximum zonal wind in each hemisphere for each pressure level and month. A similar procedure was used to quantify the strength of the Hadley circulation, using the maximum magnitude (i.e., absolute value) of the tropical MMC at $500 \mathrm{hPa}$. The change in strength or jet altitude is then estimated as the difference between experiment and control.

Throughout this manuscript, statistical significance is estimated with a standard $t$-test, using the pooled variance. The influence of serial correlation is accounted for by using the
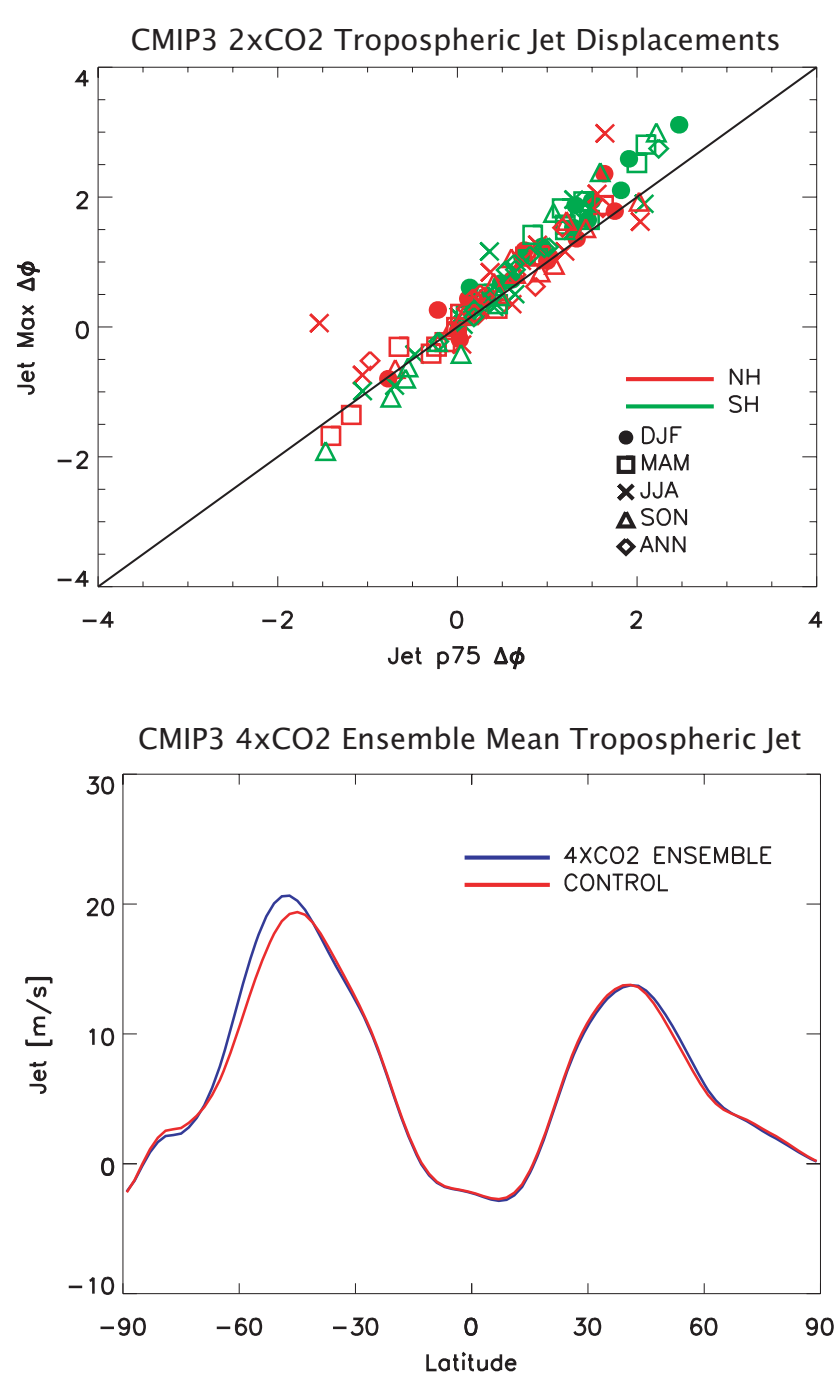

Fig. 1. (Top panel) Tropospheric poleward jet displacement [degrees latitude] based on $12 \mathrm{CMIP} 32 \times \mathrm{CO} 2$ equilibrium experiments using the maximum zonal wind method (Jet Max) and the percentile method with the 75th percentile (Jet p75). (Bottom panel) The ensemble annual zonal mean tropospheric jet $(850-300 \mathrm{hPa} U)$ response based on $101 \%$ to $4 \times \mathrm{CO} 2$ transient CMIP3 experiments, along with the corresponding control.

effective sample size, $n\left(1-\rho_{1}\right)\left(1+\rho_{1}\right)^{-1}$, where $n$ is the number of years and $\rho_{1}$ is the lag- 1 autocorrelation coefficient (Wilks, 1995).

\section{Results}

\subsection{Response to stratospheric cooling}

Figure 2 shows the annual and zonal mean temperature and wind response for the stratospheric cooling (10PLO3) experiments. Also included is the meridional temperature gradient $\left(T_{y}\right)$ response, with Southern Hemisphere $(\mathrm{SH}) T_{y}$ multiplied by -1 (and in all subsequent figures) so that 

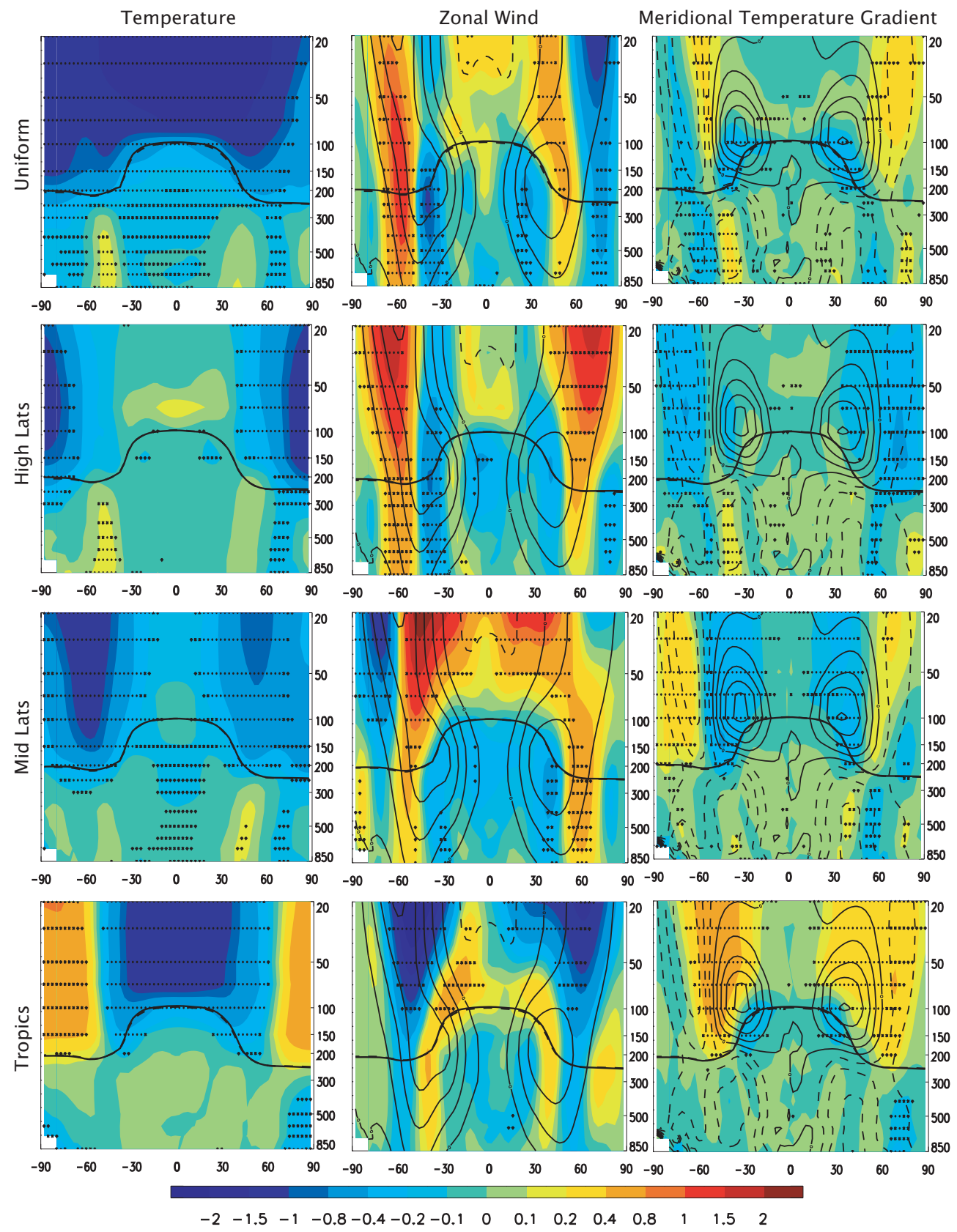

Fig. 2. Zonal annual mean (left) temperature, (center) zonal wind and (right) meridional temperature gradient response for 10PLO3 at (top) all latitudes, (middle top) high latitudes, (middle bottom) mid-latitudes and (bottom) low latitudes. Also shown is the tropopause pressure for the (dashed) control and (solid) experiment. Symbols represent significance at the $90 \%$ (diamond); $95 \%$ (cross) and $99 \%$ (dot) confidence level. Climatological $U\left(T_{y}\right)$ contour interval is $10 \mathrm{~m} \mathrm{~s}^{-1}\left(2 \times 10^{-3} \mathrm{~K} \mathrm{~km}^{-1}\right)$ with negative values dashed. $T$ units are $\mathrm{K}$.

negative $T_{y}$ always represents colder air poleward. As expected, temperatures are generally colder, by $\sim 1 \mathrm{~K}$, because of reduced solar absorption where the ozone reduction was imposed. Several non-local responses also occur, including tropospheric warming for the all-, high-, and mid-latitude experiments. These three experiments also yield an increase in zonal wind $(U)$ near $60^{\circ}$, whose magnitude decays downward through the troposphere. This $U$ increase occurs near the poleward flank of the tropospheric jet, while an opposite signed anomaly appears near the equatorward flank, indicating a poleward jet displacement. Note that reducing stratospheric ozone in the tropics $\left(10 \mathrm{PLO}_{\mathrm{TR}}\right)$ yields the opposite response; however, the magnitude of the tropospheric wind anomaly is weak and not significant.

Table 4 quantifies the annual mean poleward displacement of the tropospheric ( $850-300 \mathrm{hPa})$ jets. As suggested by 
Table 4. Tropospheric (850-300 hPa) poleward jet displacements for the (top) stratospheric cooling experiments and (middle and bottom) tropospheric heating/global warming experiments. Units are degrees latitude. CAM experiment significance is based on a Student's $t$-test and is denoted by bold $(\geq 90 \%) ; *(\geq 95 \%)$ and $* *(\geq 99 \%)$. Also included is the corresponding jet displacement based on the ensemble mean of $12 \mathrm{CMIP} 32 \times \mathrm{CO} 2$ equilibrium experiments and $10 \mathrm{CMIP} 34 \times \mathrm{CO} 2$ transient experiments.

\begin{tabular}{|c|c|c|c|c|c|c|c|c|c|c|}
\hline \multirow[t]{2}{*}{ Signal } & \multicolumn{2}{|c|}{ ANN } & \multicolumn{2}{|c|}{ DJF } & \multicolumn{2}{|c|}{ MAM } & \multicolumn{2}{|c|}{ JJA } & \multicolumn{2}{|c|}{ SON } \\
\hline & $\mathrm{NH}$ & SH & $\mathrm{NH}$ & SH & $\mathrm{NH}$ & SH & $\mathrm{NH}$ & SH & $\mathrm{NH}$ & SH \\
\hline 10PLO3 & 0.30 & $0.59^{*}$ & 0.35 & 0.64 & 0.67 & 0.10 & -0.15 & 0.72 & 0.38 & $0.87^{*}$ \\
\hline $10 \mathrm{PLO} 3_{\mathrm{HL}}$ & 0.31 & $0.40^{*}$ & -0.07 & 0.47 & 0.84 & 0.31 & 0.39 & 0.13 & 0.12 & $0.69^{*}$ \\
\hline $10 \mathrm{PLO} 3 \mathrm{ML}$ & 0.40 & 0.26 & 0.42 & 0.05 & 0.60 & 0.19 & 0.34 & 0.04 & 0.31 & $0.81^{*}$ \\
\hline $10 \mathrm{PLO} 3 \mathrm{TR}$ & -0.04 & -0.12 & -0.20 & -0.50 & -0.01 & $-\mathbf{0 . 6 0}$ & -0.05 & 0.32 & 0.14 & 0.30 \\
\hline LTHT & 0.33 & -0.13 & 0.49 & -0.17 & 0.70 & -0.34 & -0.01 & -0.17 & 0.17 & 0.18 \\
\hline $\mathrm{LTHT}_{\mathrm{HL}}$ & -0.26 & -0.16 & -0.26 & 0.01 & -0.14 & -0.46 & -0.65 & -0.18 & -0.06 & 0.01 \\
\hline $\mathrm{LTHT}_{\mathrm{ML}}$ & $0.66^{*}$ & $1.02^{* *}$ & 0.34 & $0.89^{* *}$ & 0.79 & $0.92^{* *}$ & 0.74 & $1.15^{*}$ & $0.78^{* *}$ & $1.16^{*}$ \\
\hline $\mathrm{LTHT}_{\mathrm{TR}}$ & -0.05 & -0.09 & 0.23 & -0.63 & 0.28 & -0.31 & -0.49 & 0.42 & -0.22 & 0.16 \\
\hline LTHT2x & 0.12 & $-0.73^{* *}$ & 0.66 & $-0.94^{* *}$ & 0.67 & -0.60 & -0.64 & -0.40 & -0.21 & $-0.95^{*}$ \\
\hline LTHT2x $x_{H L}$ & -0.32 & $-0.42^{*}$ & -0.19 & $-0.77^{*}$ & 0.19 & $-0.77^{*}$ & -0.94 & -0.11 & -0.29 & 0.06 \\
\hline LTHT $2 x_{M L}$ & $1.67^{* *}$ & $\mathbf{0 . 8 5}^{*}$ & $1.90^{* *}$ & $0.72^{*}$ & $1.70^{* *}$ & $1.01^{* *}$ & $1.56 * *$ & 0.93 & $1.56^{* *}$ & 0.65 \\
\hline LTHT2x & -0.20 & -0.03 & 0.39 & -0.32 & 0.36 & $-0.57^{*}$ & $-1.22^{* *}$ & 0.54 & -0.26 & 0.18 \\
\hline LTHT4x & -0.34 & $-1.12^{* *}$ & $0.63^{*}$ & $-1.37^{* *}$ & -0.06 & $-1.03^{* *}$ & $-1.49^{* *}$ & $-1.05^{*}$ & -0.41 & $-0.97^{* *}$ \\
\hline LTHT4 $x_{T R}$ & -0.06 & 0.26 & $1.20^{* *}$ & 0.27 & $1.32^{* *}$ & $-0.93^{*}$ & $-1.8^{* *}$ & $1.04 *$ & $-0.97^{* *}$ & 0.72* \\
\hline $\mathrm{UTHT}_{\mathrm{ML}}$ & $0.65^{*}$ & $0.53^{* *}$ & 0.59 & 0.22 & $1.10^{*}$ & $0.75^{*}$ & 0.43 & 0.53 & 0.46 & 0.69 \\
\hline $2 \times \mathrm{CO} 2$ & $1.08^{* *}$ & 0.09 & $1.34^{* *}$ & -0.10 & $1.70^{* *}$ & 0.28 & 0.50 & 0.35 & $0.71^{* *}$ & -0.20 \\
\hline $8 \times \mathrm{CO} 2$ & $1.50^{* *}$ & 0.03 & $1.44^{* *}$ & -0.21 & $2.65^{* *}$ & $1.27^{* *}$ & 0.55 & 0.04 & $1.50^{* *}$ & $-1.05^{*}$ \\
\hline $2 \times \mathrm{CO} 2$ CMIP 3 & 0.46 & 0.73 & 0.58 & 1.22 & -0.01 & 1.13 & 0.56 & 0.36 & 0.67 & 0.20 \\
\hline $4 \times \mathrm{CO} 2 \mathrm{CMIP} 3$ & 0.98 & 1.74 & 0.66 & 1.72 & 0.81 & 2.20 & 1.54 & 1.91 & 0.98 & 1.14 \\
\hline
\end{tabular}

Fig. 2, stratospheric cooling generally yields a poleward displacement, of about $0.5^{\circ}$ in each hemisphere. Cooling in the tropical stratosphere yields the opposite, but the equatorward shift is small and not significant. Note that these changes are generally similar in both hemispheres, and across the four seasons. Furthermore, Table 5 shows the additional metrics of tropical displacement are generally consistent with the jet response. For $10 \mathrm{PLO} 3,10 \mathrm{PLO} 3_{\mathrm{HL}}$ and $10 \mathrm{PLO} 3_{\mathrm{ML}}$, both $P-E$ and MMC yield annual mean poleward displacement, although smaller than that based on the tropospheric jet.

\subsection{Response to tropospheric heating}

\subsubsection{Sensitivity to the latitudinal distribution of near-surface heating}

Figure 3 shows the $T, U$ and $T_{y}$ response for the lower tropospheric heating experiments (LTHT). Similar to $\mathrm{CO}_{2}$ forcing, globally uniform near-surface heating causes a local warming maximum in the tropical upper troposphere due to moist convection, and high-latitude near-surface warming amplification due to snow and ice albedo feedbacks, as well as the higher static stability in polar regions. The zonal wind response to LTHT implies a poleward displacement of the $\mathrm{NH}$ tropospheric jet, but not the SH one. These shifts, however, are not statistically significant (see Table 4) in the annual mean or in any season. We note that in coupled ocean- atmosphere models (and observations), the SH warming will be much less than that here due to uptake of heat by the Southern Ocean, which will affect how much the jet shifts.

Heating the individual latitude bands separately yields maximum warming at the heated latitudes, though with some spillover to most of the troposphere in the cases of $\mathrm{LTHT}_{\mathrm{HL}}$ and $\mathrm{LTHT}_{\mathrm{ML}}$. Generally, however, the latitudes that are heated experience the largest temperature response, which is consistent with a down-gradient eddy heat flux response (i.e., oriented away from the latitude of maximum heating; not shown). There are also some dynamically induced remote cooling responses, including significant stratospheric cooling for LTHT and weaker tropospheric high-latitude cooling for LTHT $_{\mathrm{TR}}$.

A much stronger impact on tropical width occurs with heating restricted to midlatitudes than for the globally uniform case. LTHT $_{\mathrm{ML}}$ shows both reduced $U$ on the equatorward flank of the jet and increased $U$ on the poleward jet flank, yielding significant poleward jet displacement of $0.66^{\circ}$ in the $\mathrm{NH}$ and $1.02^{\circ}$ in the SH. Significant displacements also occurred in experiments where either low or high latitudes were heated at the same time as mid-latitudes (LTHT $_{\text {TRML }}$ and LTHT $_{\text {MLHL }}$, respectively), supporting the robustness of this result. For example, Table 5 shows simultaneous heating of the low- and mid-latitudes yields a poleward jet displacement of $0.41^{\circ}$ in the $\mathrm{NH}$ and $0.20^{\circ}$ in the SH. LTHT TRML jet displacements become significant, and 
Table 5. Annual mean poleward displacement (degrees latitude) of several measures of tropical width for the (top) stratospheric cooling experiments and (middle and bottom) tropospheric heating/global warming experiments, including the CMIP3 $2 \times \mathrm{CO} 2$ and $4 \times \mathrm{CO} 2$ ensemble mean. These measures are based on the subtropical dry zone (precipitation minus evaporation, $P-E$ ), mean meridional mass circulation (MMC) and the tropospheric $(850-300 \mathrm{hPa})$ jet. See text for further description. Significance is denoted as in Table 4.

\begin{tabular}{|c|c|c|c|c|c|c|}
\hline \multirow[t]{2}{*}{ Signal } & \multicolumn{2}{|c|}{$\mathrm{P}-\mathrm{E}$} & \multicolumn{2}{|c|}{ MMC } & \multicolumn{2}{|c|}{ Jet } \\
\hline & $\mathrm{NH}$ & SH & $\mathrm{NH}$ & $\mathrm{SH}$ & $\mathrm{NH}$ & $\mathrm{SH}$ \\
\hline 10PLO3 & 0.29 & $0.30^{* *}$ & 0.11 & 0.15 & 0.30 & $0.59^{*}$ \\
\hline $10 \mathrm{PLO}^{\mathrm{HL}}$ & 0.21 & $0.22^{*}$ & 0.04 & 0.17 & 0.31 & $0.40^{*}$ \\
\hline $10 \mathrm{PLO} 3_{\mathrm{ML}}$ & 0.23 & $0.23^{*}$ & 0.12 & 0.13 & 0.40 & 0.26 \\
\hline${ }_{10 \mathrm{PLO}} \mathrm{TR}$ & -0.13 & 0.03 & -0.18 & -0.02 & -0.04 & -0.12 \\
\hline LTHT & 0.14 & $0.21^{*}$ & -0.02 & 0.02 & 0.33 & -0.13 \\
\hline $\mathrm{LTHT}_{\mathrm{HL}}$ & -0.13 & 0.13 & -0.07 & 0.03 & -0.26 & -0.16 \\
\hline $\mathrm{LTHT}_{\mathrm{ML}}$ & $0.61^{* *}$ & $0.67 * *$ & $0.32^{*}$ & $0.29^{* *}$ & $0.66^{*}$ & $1.02^{* *}$ \\
\hline $\mathrm{LTHT}_{\mathrm{TR}}$ & -0.18 & 0.01 & -0.17 & -0.11 & -0.05 & -0.09 \\
\hline LTHT2x & 0.16 & 0.01 & -0.16 & -0.04 & 0.12 & $-0.73^{* *}$ \\
\hline LTHT2 $x_{H L}$ & $-0.41^{* *}$ & 0.02 & -0.17 & -0.13 & -0.32 & $-0.42^{*}$ \\
\hline LTHT $2 x_{M L}$ & $1.03^{* *}$ & $0.64^{* *}$ & $0.79^{* *}$ & $\mathbf{0 . 3 3}^{*}$ & $1.67^{* *}$ & $0.85^{*}$ \\
\hline LTHT2x $x_{\text {TR }}$ & $-0.34^{*}$ & 0.01 & $-0.36^{* *}$ & -0.07 & -0.20 & -0.03 \\
\hline MTHT2x & $0.66^{* *}$ & $0.41^{* *}$ & $0.47^{* *}$ & 0.18 & $0.74^{*}$ & $0.48^{*}$ \\
\hline MTHT2 $x_{H L}$ & $-0.30^{*}$ & $-0.22 *$ & -0.10 & -0.11 & -0.29 & $-0.69^{* *}$ \\
\hline MTHT2 $x_{M L}$ & $1.16^{* *}$ & $1.03^{* *}$ & $0.91^{* *}$ & $0.40^{* *}$ & $1.46^{* *}$ & $1.29^{* *}$ \\
\hline MTHT2x & $-0.43^{* *}$ & 0.05 & -0.10 & $\mathbf{0 . 2 3}^{*}$ & 0.02 & $0.45^{*}$ \\
\hline LTHT4x & -0.18 & -0.05 & $-0.31^{*}$ & -0.14 & -0.34 & $-1.12^{* *}$ \\
\hline LTHT4x $x_{\text {TR }}$ & $-0.41^{* *}$ & 0.06 & $-0.43^{* *}$ & 0.11 & -0.06 & 0.26 \\
\hline MTHT & 0.24 & $0.20^{*}$ & 0.01 & 0.10 & 0.31 & 0.23 \\
\hline MTHT4x & $0.74^{* *}$ & $0.55^{* *}$ & $0.41^{* *}$ & $\mathbf{0 . 3 2} 2^{* *}$ & $0.74^{* *}$ & $0.42^{*}$ \\
\hline $\mathrm{UTHT}_{\mathrm{ML}}$ & $0.40^{* *}$ & $0.26^{*}$ & $0.28^{*}$ & $0.20^{*}$ & $0.65^{*}$ & $0.53^{* *}$ \\
\hline $\mathrm{LTHT}_{\mathrm{TRML}}$ & $\mathbf{0 . 3 4} *$ & $0.29^{* *}$ & 0.02 & 0.02 & 0.41 & 0.20 \\
\hline LTHT2 $x_{\text {TRML }}$ & $0.60^{* *}$ & $0.36^{* *}$ & 0.21 & $0.18^{*}$ & $0.97^{* *}$ & $0.53^{* *}$ \\
\hline $\mathrm{LTHT}_{M L H L}$ & $0.28^{*}$ & $0.33^{* *}$ & 0.16 & 0.07 & 0.28 & 0.14 \\
\hline${\text { LTHT } 2 \mathrm{x}_{M L H L}}$ & $0.56^{* *}$ & $0.56^{* *}$ & $0.43^{* *}$ & $0.33^{* *}$ & 0.43 & 0.39 \\
\hline $\mathrm{LTHT}_{10 P L O 3}$ & 0.02 & 0.11 & -0.09 & -0.02 & -0.13 & -0.32 \\
\hline LTHT $2 \mathrm{x}_{1 O P L O 3}$ & $0.26^{*}$ & $0.25^{*}$ & 0.01 & 0.11 & 0.18 & -0.01 \\
\hline LTHT $4 \mathrm{x}_{10 P L O 3}$ & 0.17 & 0.05 & -0.07 & -0.06 & -0.20 & $-0.92^{*}$ \\
\hline $2 \times \mathrm{CO} 2$ & $\mathbf{0 . 8 3}{ }^{* *}$ & $0.60^{* *}$ & $0.81^{* *}$ & $0.42^{* *}$ & $1.08^{* *}$ & 0.09 \\
\hline $8 \times \mathrm{CO} 2$ & $0.85^{* *}$ & $1.56^{* *}$ & $1.48^{* *}$ & $1.41^{* *}$ & $1.50^{* *}$ & 0.03 \\
\hline $2 \times \mathrm{CO} 2$ CMIP 3 & 0.31 & 0.90 & 0.52 & 0.86 & 0.46 & 0.73 \\
\hline $4 \times \mathrm{CO} 2$ CMIP3 & 1.23 & 1.33 & 0.73 & 1.34 & 0.98 & 1.74 \\
\hline
\end{tabular}

approximately double in magnitude, when the heating rate is doubled (LTHT2 $\mathrm{x}_{\text {TRML }}$ ).

Heating at high-latitudes ( LTHT $_{\mathrm{HL}}$ ) produced an opposite result, reducing $U$ on the poleward jet flank to produce an equatorward jet displacement of $-0.42^{\circ}$ over the two hemispheres, about a quarter of the poleward shift with midlatitude heating. Tropical heating $\left(\mathrm{LTHT}_{\mathrm{TR}}\right)$ increased the peak $U$ throughout the atmosphere, but without significantly shifting the jet position except upward. While the above conclusions are based on jet shifts, similar responses are found among other tropical displacement measures (Ta- ble 5), especially for the midlatitude heating which produced the strongest response.

Figure 4 shows the poleward displacement of the maximum meridional tropospheric temperature gradient, and the jet, for LTHT experiments as a function of pressure. LTHT $_{\mathrm{HL}}$ yields equatorward displacement of the maximum $T_{y}$ whereas $\mathrm{LTHT}_{\mathrm{ML}}$ features poleward displacement. This is consistent with the corresponding $\mathrm{LTHT}_{\mathrm{HL}}$ and $\mathrm{LTHT}_{\mathrm{ML}}$ tropospheric jet displacement - both quantities move poleward or equatorward together, in general agreement with thermal wind balance. For LTHT $_{\mathrm{ML}}$, heating of the mid-latitudes 

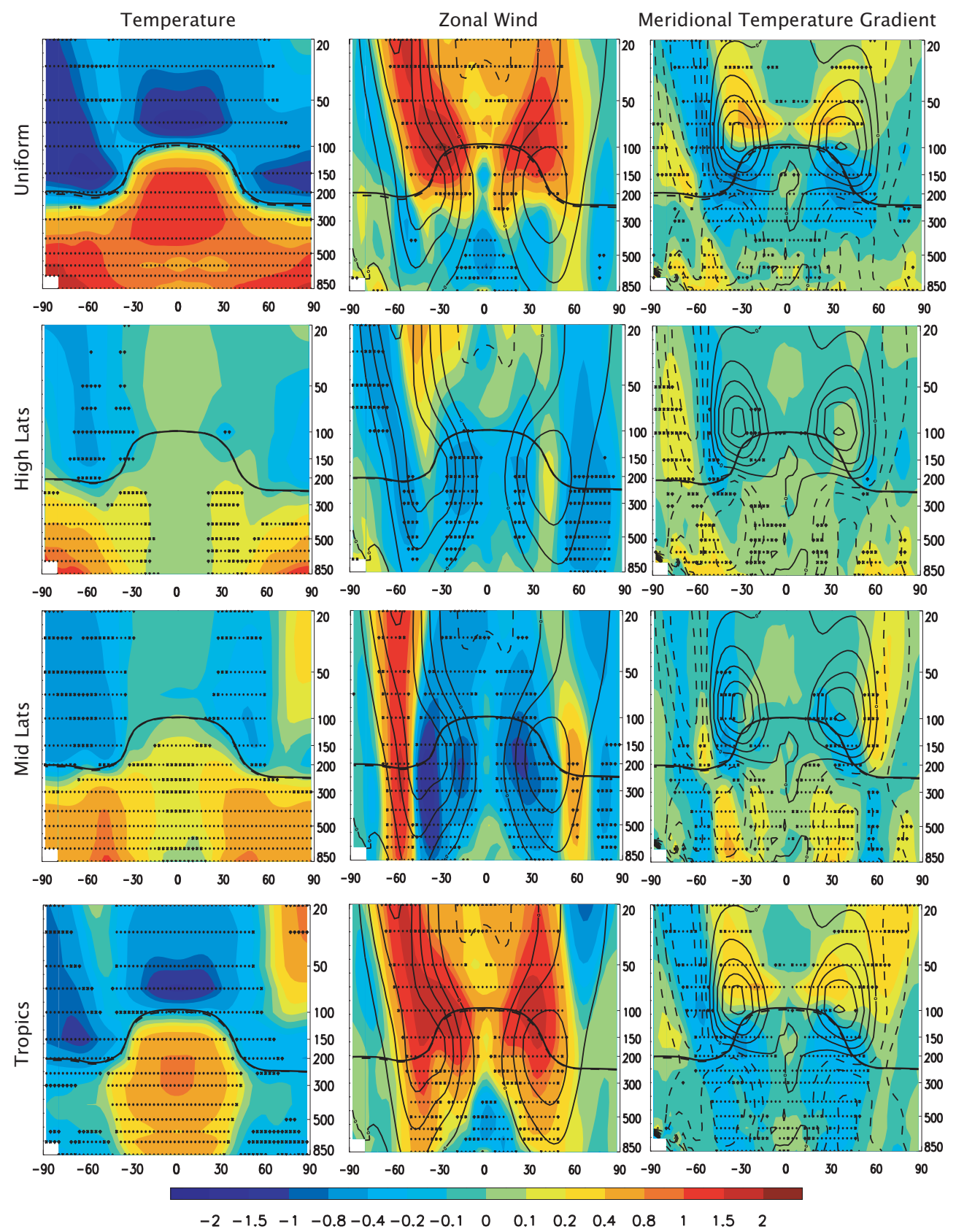

Fig. 3. As in Fig. 2, but based on the lower tropospheric heating (LTHT) experiments.

weakens the temperature gradient on the equatorward flank of the maximum $T_{y}$, but increases it on the poleward flank, as shown in Fig. 3. The tropospheric jet then responds by shifting poleward. The opposite occurs for $\mathrm{LTHT}_{\mathrm{HL}}$. Small displacements of the maximum $T_{y}$ generally occur for $\mathrm{LTHT}_{\mathrm{TR}}$, in agreement with the small jet displacement. Over all experiments included in Fig. 4, the correlation between displacements of the maximum $T_{y}$ and tropospheric jet is 0.81 in the $\mathrm{NH}$ and 0.92 in the SH. Although not shown, displacements of the maximum $T_{y}$ are also similar to that of the tropospheric jet for the stratospheric cooling experiments.
Butler et al. (2010, 2011) also examined the impact of tropical heating, and found a shift similar to that obtained here with heating from $0-60^{\circ} \mathrm{N} / \mathrm{S}$ (LTHT TRML), in contrast to our null result with tropical-only heating. While this result seems contradictory, the tropical heating employed by Butler et al. $(2010,2011)$ differed from ours by projecting significantly onto the mid-latitude isentropes, weakening baroclinicity in the subtropics while strengthening it in the mid-latitudes. Poleward jet displacement is also absent in LTHT4 $\mathrm{x}_{\mathrm{TR}}$ (Table 4), which features a heating rate more comparable to Butler et al. $(2010,2011)$. These results taken 

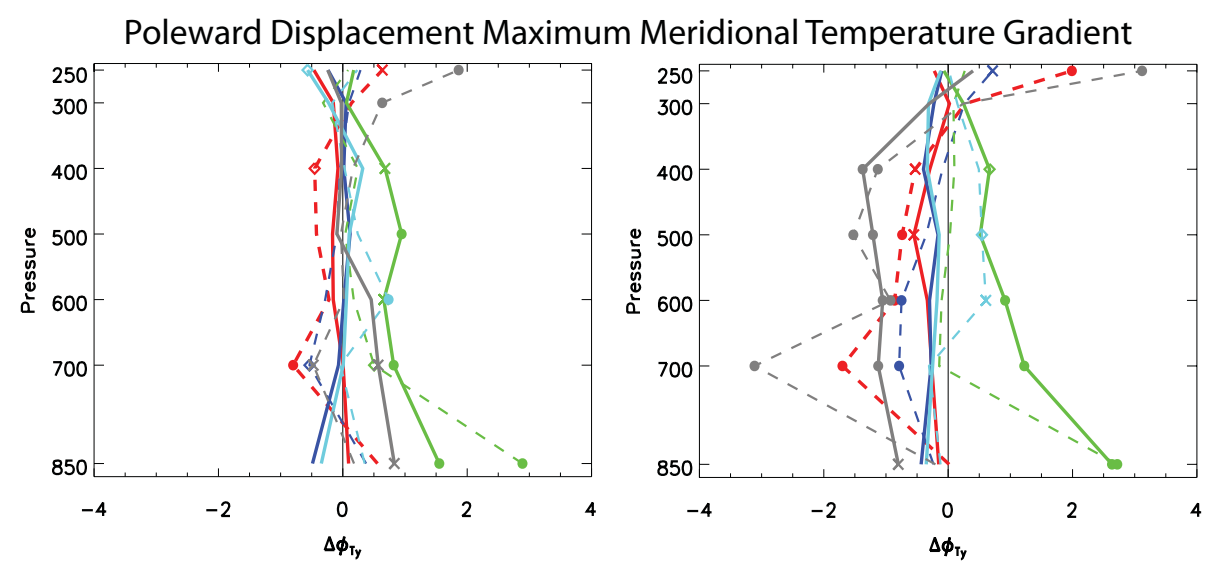

Poleward Displacement Tropospheric Jet
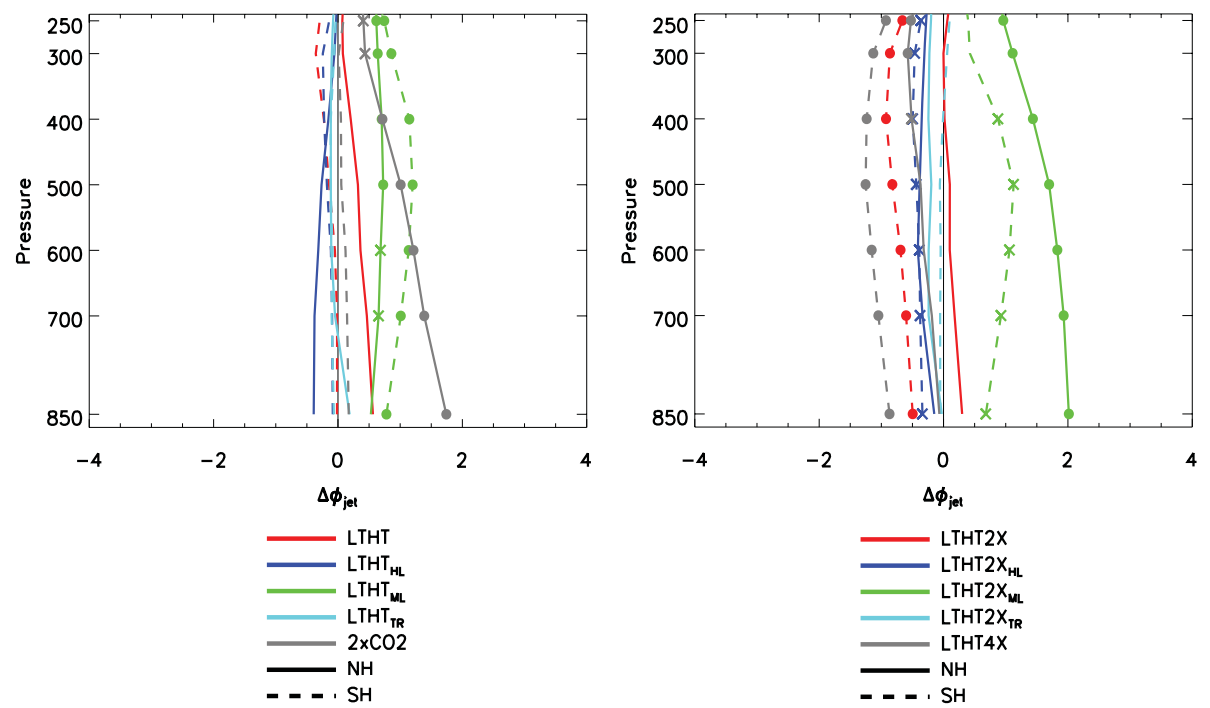

Fig. 4. Poleward displacement of the (top) latitude of the maximum tropospheric temperature gradient ( $\left.T_{y}\right)$ and (bottom) jet for the Northern (solid) and Southern (dashed) Hemisphere for various LTHT and $2 \times \mathrm{CO} 2$ experiments. Symbols represent significance at the $90 \%$ (diamond); $95 \%$ (cross) and $99 \%$ (dot) confidence level.

together are consistent with a particular sensitivity of the jet to heating in highly baroclinic, midlatitude regions, with relatively little sensitivity in the tropics.

Figure 5 further shows that geostrophic adjustment to the altered meridional temperature gradient explains most of the annual mean tropospheric wind response. Zonal wind shear for each pressure level is estimated from the corresponding meridional temperature gradient, according to thermal wind balance. To estimate the zonal wind, we use the $900 \mathrm{hPa}$ zonal wind as a boundary condition. Taking the difference between the experiment and control yields the corresponding response, as shown in the center panel of Fig. 5. The actual zonal wind response closely corresponds to that estimated from thermal wind balance. The difference between the two (estimate - actual) shows no significant differences at most latitudes, except near the equator where meridional temperature gradients are small and geostrophy becomes a poor approximation. Thus, most of the tropospheric jet shift in our LTHT experiments is consistent with a geostrophic adjustment to the altered meridional temperature gradient.

Although the eddy-driven jet is not the focus of this study, in our experiments displacements of the surface wind (a measure of the eddy-driven jet) are similar to those of the tropospheric jet. For the suite of lower tropospheric heating and stratospheric cooling experiments, and $2 \times \mathrm{CO} 2$, the corresponding correlation is 0.92 in the $\mathrm{NH}$ and 0.91 in the $\mathrm{SH}$. This is despite the fact that transient eddies should play a more important role in displacements of this jet. We also note that displacements of the surface wind correspond to those of the maximum Eady growth rate (Lindzen and Farrell, 1980). For example, the correlation between displacements of the maximum surface wind and the maximum $850 \mathrm{hPa}$ Eady growth rate is 0.80 for the $\mathrm{NH}$ and 0.84 for the $\mathrm{SH}$. Since the Eady growth rate is proportional to $T_{y}$, this is consistent 

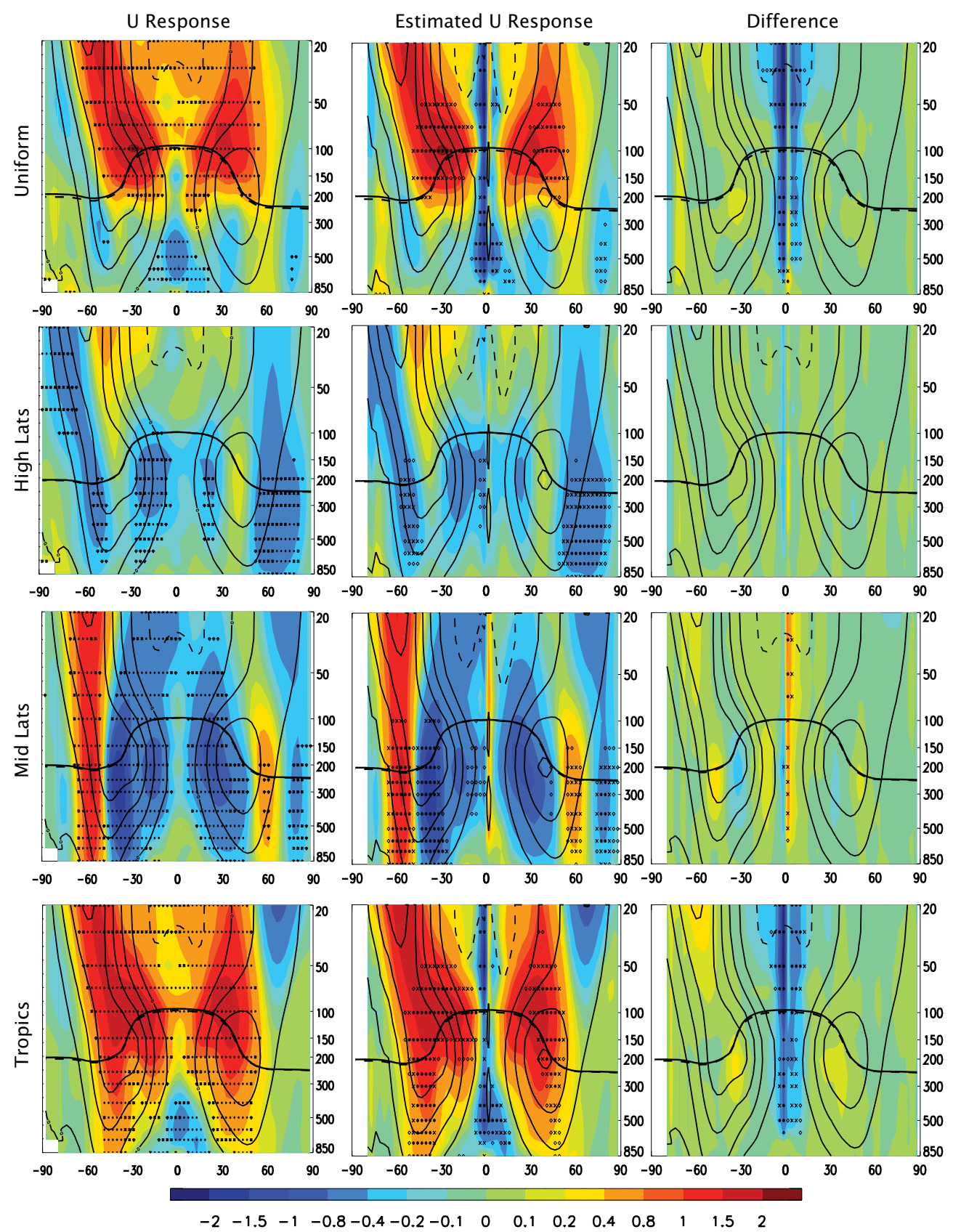

Fig. 5. Zonal annual mean zonal wind response (left), estimated zonal wind response (center) and difference (estimate-actual; right) for the lower-tropospheric heating experiments. The estimated $U$ response is based on thermal wind balance, using the $900 \mathrm{hPa}$ winds as a lower boundary condition. Also shown is the tropopause pressure for the (dashed) control and (solid) experiment. Symbols represent significance at the $90 \%$ (diamond); $95 \%$ (cross) and $99 \%$ (dot) confidence level. Climatological $U$ contour interval is $10 \mathrm{~m} \mathrm{~s}^{-1}$ with negative values dashed. Left panels ( $U$ response) are as in Fig. 3.

with our baroclinicity argument for tropospheric jet displacements and with the notion that storms tend to form in regions of high baroclinicity.

We note that the changes during El Niño events are consistent with our results. El Niño is associated with tropical tropospheric warming by warmer Pacific SSTs, mid-latitude tropospheric cooling due to eddy-driven upward motion, and high-latitude tropospheric warming (Lu et al., 2008). The tropospheric jet, in turn, intensifies near the equatorward jet flank and weakens near the poleward flank, resulting in a strengthening and equatorward shift of the jet. The stronger jet is consistent with tropical warming and our LTHT $_{\mathrm{TR}}$ experiment. The equatorward shift is consistent with cooling in 
the mid-latitudes and warming in the high-latitudes, as illustrated by our $\mathrm{LTHT}_{\mathrm{ML}}$ and $\mathrm{LTHT}_{\mathrm{HL}}$ experiments.

\subsubsection{GFDL tropospheric heating experiments}

To evaluate the robustness of the CAM responses to lowertropospheric heating, we conducted analogous experiments with the GFDL AM2.1 (Anderson et al., 2004) using climatological SSTs. Figure 6 shows the corresponding annual mean temperature and zonal wind responses for LTHT2x, LTHT2 $x_{T R}$, LTHT2 $x_{M L}$, LTHT2 $x_{H L}$. Results are similar to that based on CAM (Fig. 3). Heating of the tropics results in negligible jet displacement of $-0.09^{\circ}$ in the $\mathrm{NH}$ and $-0.04^{\circ}$ in the SH. However, high-latitude heating results in equatorward jet displacement $\left(-0.26^{\circ}\right.$ in the $\mathrm{NH}$ and $-0.10^{\circ}$ in the $\mathrm{SH}$ ) and mid-latitude heating results in poleward jet displacement of $0.75^{\circ}$ in the $\mathrm{NH}\left(95 \%\right.$ significant) and $0.24^{\circ}$ in the SH. The weaker GFDL response - particularly the SH response to mid-latitude heating - is likely due to the use of climatological SSTs, which mutes the tropospheric response. Repeating the GFDL mid-latitude heating experiment with double the heating rate $\left(0.4 \mathrm{~K} \mathrm{day}^{-1}\right)$ results in significant poleward jet displacement in both the $\mathrm{NH}$ and $\mathrm{SH}$ at $1.98^{\circ}$ and $0.45^{\circ}$, respectively (not shown). We note that the main discrepancy between CAM and GFDL occurs for uniform heating of all latitudes. GFDL LTHT2x yields poleward jet displacement of $0.13^{\circ}$ in the $\mathrm{NH}$ and $0.39^{\circ}$ in the $\mathrm{SH}$, the latter of which is significant at the $90 \%$ confidence level. Although CAM LTHT2x yields similar, but weak, poleward jet displacement in the $\mathrm{NH}\left(0.12^{\circ}\right)$, significant poleward jet displacement in the SH occurs $\left(-0.73^{\circ}\right.$; Table 4$)$.

\subsubsection{Evidence of nonlinear responses}

Table 4 shows that the LTHT responses are similar, but generally larger, when the heating rate is doubled (LTHT2x). This includes tropical expansion for mid-latitude heating, tropical contraction for high-latitude heating, and negligible displacement for tropical heating. Unlike LTHT however, LTHT2x yields an "overall" equatorward jet displacement $(\mathrm{NH}+\mathrm{SH})$ of $0.61^{\circ}$, which is dominated by the $\mathrm{SH}$ jet which moves equatoward by $0.73^{\circ}$. Similarly, LTHT4x shows significant equatorward jet displacement of $1.46^{\circ}$, which again is dominated by the $\mathrm{SH}$ jet.

The bottom panel of Fig. 4 shows that the relationship between displacements of the maximum meridional tropospheric temperature gradient and the tropospheric jet also applies for the LTHT2x experiments. Note that as the heating rate is increased and the tendency for jet displacement is equatorward, the maximum $T_{y}$ also shows a similar tendency of equatorward displacement. LTHT4x, for example, shows significant equatorward displacement of the maximum $T_{y}$ in both the $\mathrm{SH}$ and $\mathrm{NH}$, in agreement with equatorward jet displacement (Table 4), particularly in the SH.
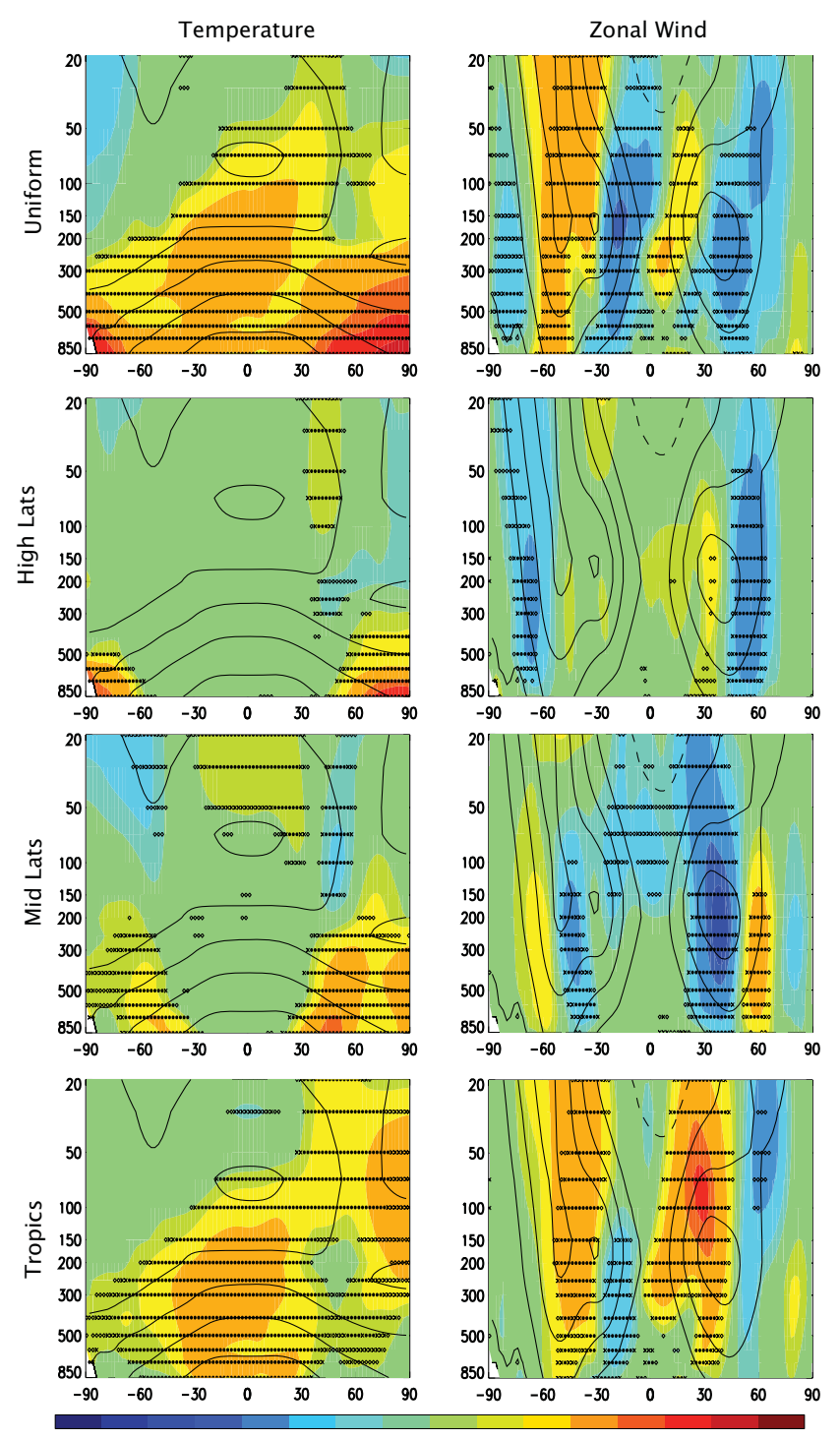

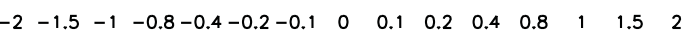

Fig. 6. Zonal annual mean temperature (left) and zonal wind (right) response to heating $\left(0.2 \mathrm{~K} \mathrm{day}^{-1}\right)$ the lower troposphere using the GFDL AM2.1 model. Symbols represent significance at the $90 \%$ (diamond); $95 \%$ (cross) and 99\% (dot) confidence level. Climatological $U$ contour interval (thin black) is $10 \mathrm{~m} \mathrm{~s}^{-1}$ with negative values dashed. Climatological $T$ contour interval is $10 \mathrm{~K}$.

One aspect of the uniform heating experiments that can be deduced from the above figures (e.g., Fig. 3) is that the responses are often nonlinear. For example, the sum of the poleward SH jet displacements in the $\mathrm{LTHT}_{\mathrm{TR}}, \mathrm{LTHT}_{\mathrm{ML}}$ and $\mathrm{LTHT}_{\mathrm{HL}}$ experiments is $0.77^{\circ}$, while the shift with uniform heating is smaller and in the opposite direction $\left(-0.13^{\circ}\right)$. This behavior recurs in the LTHT $2 x$ experiments, with values of $0.40^{\circ}$ and $-0.73^{\circ}$ respectively. This nonlinear response is similar to the idealized experiments of Butler et al. (2010). This nonlinearity could be caused by the effects of localized heating on the vertical propagation of wave energy, and 

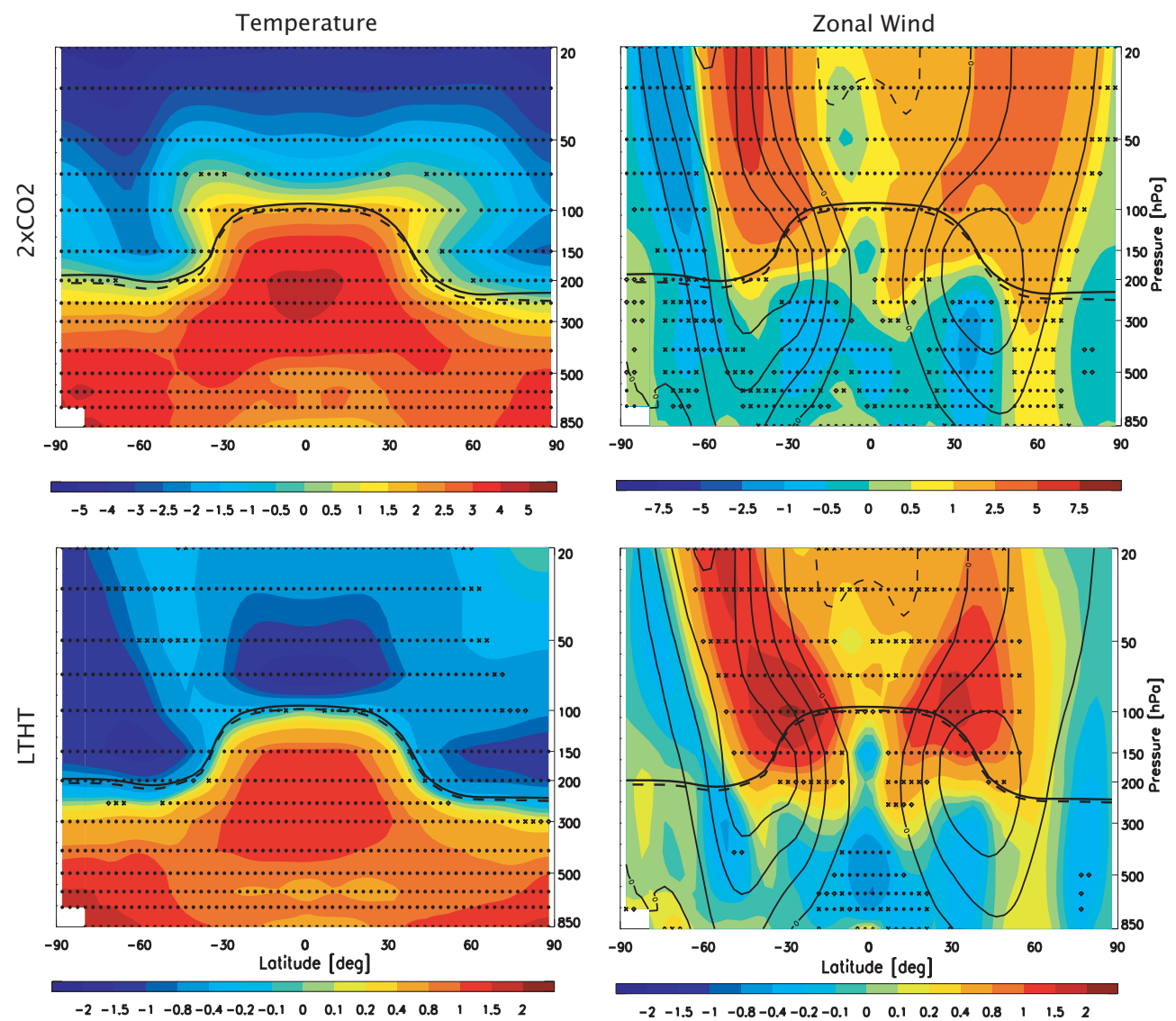

Fig. 7. $2 \times \mathrm{CO} 2$ (top) and LTHT (bottom) annual mean temperature (left) and zonal wind (right) response. LTHT results, and significance symbols, are as in Fig. 3. Note contour differences between $2 \times \mathrm{CO} 2$ and LTHT.

linear interference effects between the wave response and the background stationary wave (Smith et al., 2010; Fletcher and Kushner, 2011).

We note that the amplitude of jet displacement, however, appears to be more linear based on CMIP3 $\mathrm{CO}_{2}$ experiments. Using the $104 \times \mathrm{CO} 2 \mathrm{CMIP} 3$ models, we calculate the jet displacement using the $25 \mathrm{yr}$ prior to doubling and the 25 yr prior to quadrupling (each compared to the corresponding control). For $4 \times \mathrm{CO} 2$, the ensemble annual mean $\mathrm{NH}$ jet displacement is $0.98^{\circ}$, compared to $0.35^{\circ}$ for $2 \times \mathrm{CO} 2$; in the $\mathrm{SH}$, the corresponding jet displacements are $1.74^{\circ}$ and $0.81^{\circ}$, respectively. Thus, doubling the $\mathrm{CO}_{2}$ forcing tends to yield double the jet displacement in CMIP3 experiments. This is similar to Wang et al. (2012), who found a linear relationship between the amplitude of the temperature response in the tropics and the tropospheric jet shift using a dry, idealized model (however, the eddy-driven jet exhibited an abrupt shift when tropical warming exceeded a critical amplitude).

Nearly all of the CAM heating experiments, as well as $2 \times \mathrm{CO} 2$, weaken the mean meridional circulation and strength of the tropospheric jet (not shown), in agreement with behavior of other GCMs and explainable by thermodynamic arguments (Held and Soden, 2006). LTHT $_{\mathrm{TR}}$, how- ever, strengthens the tropical circulation, with a $2 \%$ increase in jet strength and a $4 \%$ increase in mean meridional circulation strength. This strengthening increases to $5 \%$ and $7 \%$, respectively, for LTHT2X 2 , so this particular result is relatively linear. These latitudinally restricted heating responses are consistent with Brayshaw et al. (2008).

\subsection{Comparison of greenhouse gas warming and lower-tropospheric heating}

Figure 7 shows the annual mean $T$ and $U$ response for LTHT and $2 \times \mathrm{CO} 2$. Both feature similar patterns of warming, with maximum warming in the tropical upper troposphere and at high-latitudes. Both also feature an increase in the height of the tropopause, as well as an upward displacement of the tropospheric jets $(\sim 10 \mathrm{hPa}$ for $2 \times \mathrm{CO} 2$ and $\sim 5 \mathrm{hPa}$ for LTHT), which generally occurs with tropospheric heating (e.g., Lorenz and DeWeaver, 2007). The zonal jet displacement is also similar for the two experiments, with small SH displacements and larger NH poleward displacements, the latter of which is reminiscent of the positive NAM pattern. Note that the LTHT signal is much weaker than $2 \times \mathrm{CO} 2$. However, the global annual mean 
surface temperature response for LTHT is also much weaker: $0.91 \mathrm{~K}$ versus $2.52 \mathrm{~K}$ for $2 \times \mathrm{CO} 2$.

Our experiments from Sect. 3.1 show that stratospheric cooling causes poleward jet displacement. Therefore, one reason why the LTHT experiments may yield less poleward jet displacement than those of $2 \times \mathrm{CO} 2$, is because $2 \times \mathrm{CO} 2$ is associated with significant stratospheric cooling due to increased longwave emission to space; LTHT, however, has no directly imposed stratospheric cooling (although there is an indirect stratospheric cooling response). This was evaluated by rerunning the LTHT, LTHT2x and LTHT4x experiments, but with a $10 \%$ stratospheric ozone reduction $\left(\right.$ LTHT $_{10 \text { PLO3 }}$, LTHT2 $_{10 \text { PLO3 }}$, LTHT4 $\left.x_{10 \text { PLO3 }}\right)$. For both LTHT2x and LTHT4x, adding stratospheric cooling yields less equatorward jet displacement, particularly the $\mathrm{SH}$ jet for LTHT2x, but the differences are generally not large (Table 5)). This suggests that the tropospheric warming is more important than the stratospheric cooling.

\section{Discussion of expansion scenarios}

Prior studies have attributed tropical expansion in a warmer climate to increases in the tropopause height (e.g., Lorenz and DeWeaver, 2007; Williams, 2006) and/or extratropical dry static stability (e.g., Frierson et al., 2007; Lu et al., 2007). Figure 8 shows the changes in these two quantities, in addition to the $500 \mathrm{hPa} T_{y}$ change and its climatology for four of the tropospheric heating experiments. These four experiments were chosen because they allow the evaluation of these previously proposed mechanisms. The top two panels compare the response based on heating of the mid-latitudes in either the lower $\left(\mathrm{LTHT}_{\mathrm{ML}}\right)$ or upper $\left(\mathrm{UTHT}_{\mathrm{ML}}\right)$ troposphere. Of the two, the latter results in a larger increase in gross dry static stability of mid-latitudes, as expected. Although both experiments yield poleward jet displacement, tropical expansion is generally larger with LTHT $_{M L}$. Table 4 shows this is particularly true in the $\mathrm{SH}$, where the annual mean jet displacement is $1.02^{\circ}$ for $\mathrm{LTHT}_{\mathrm{ML}}$ versus $0.53^{\circ}$ for $\mathrm{UTHT}_{\mathrm{ML}}$. Similar conclusions exist based on the other metrics of tropical expansion (Table 5), particularly $P-E$. The larger LTHT $_{\mathrm{ML}}$ poleward jet displacement is inconsistent with a smaller increase in stability; however, it is consistent with thermal wind balance and a larger poleward displacement of the $500 \mathrm{hPa}$ SH $T_{y}$.

The bottom two panels show that heating of the highlatitudes and tropics results in an increase in tropopause height (decrease in pressure), yet neither experiment is associated with tropical expansion. LTHT2 $\mathrm{x}_{\mathrm{HL}}$ actually yields significant equatorward jet displacement of $-0.74^{\circ}\left(-0.32^{\circ}\right.$ and $-0.42^{\circ}$ for $\mathrm{NH}$ and $\mathrm{SH}$, respectively) and LTHT $2 \mathrm{x}_{\mathrm{TR}}$ yields negligible jet displacement of $-0.23^{\circ}$ (Table 4). These responses are again consistent with the change in $T_{y}$ at $500 \mathrm{hPa}$, with a weakening of $T_{y}$ at high latitudes for LTHT $2 \mathrm{x}_{\mathrm{HL}}$, and a reinforcement of the climatological $T_{y}$ for
LTHT2 $x_{\text {TR }}$. These results suggest the importance of other mechanisms in driving jet displacements, at least using CAM under our experimental design.

\subsection{Stratospheric pathway}

Section 3.1 showed cooling of the high-latitude stratosphere resulted in poleward jet displacement. Table 4 shows the largest $\mathrm{NH}$ jet displacements in response to stratospheric cooling occur during March-April-May (MAM), and the equivalent season in the $\mathrm{SH}$ (SON) similarly shows the largest response in its jet. The maximum spring response is likely due to a combination of two factors: the presence of solar radiation, so that the imposed ozone loss results in stratospheric cooling; and westerly stratospheric flow, which is conducive to strong planetary wave-mean flow interaction. The cooling of the high-latitude stratosphere increases the local meridional temperature gradient, and the stratospheric vortices in both hemispheres intensify in accord with thermal wind balance. The downward propagation of the stratospheric wind anomaly may be related to enhanced equatarward refraction of Rossby waves (Shindell et al., 2001; Rind et al., 2005). As a diagnostic tool to estimate the importance of this "stratospheric pathway", we estimate the wave refraction $(\lambda)$ as the ratio of meridional to vertical Eliassen Palm (EP) flux:

$\lambda=\frac{-\overline{u^{*} v^{*}}}{\frac{f R_{\mathrm{d}} \bar{v}^{*} T^{*}}{\mathrm{~N}^{2} \mathrm{H}}}$,

where $\overline{u^{*} v^{*}}$ is the meridional eddy momentum flux, $\overline{v^{*} T^{*}}$ is the meridional eddy heat flux, $N$ is the Brunt-Vaisala frequency, $R_{\mathrm{d}}$ is the dry air gas constant, $H$ is the scale height, $f$ is the Coriolis parameter and primes denote a zonal deviation. Because both eddy fluxes are estimated from monthly data, $\lambda$ represents the refraction of the quasi-stationary, as opposed to the transient, waves.

Table 6 shows that all stratospheric cooling experiments feature an increase in MAM NH wave refraction by $15-35 \%$ - the season of maximum poleward jet displacement in the NH. Figure 9 shows the MAM responses of $T, U$ and $T_{y}$ for one stratospheric cooling experiment, $10 \mathrm{PLO}_{\mathrm{HL}}$. Also included is the leading pattern of zonal wind anomalies, and the mean meridional circulation, associated with the NAM/SAM pattern. This pattern is based on a principal component analysis of geopotential heights for the domains extending from $20-90^{\circ} \mathrm{N} / \mathrm{S}$ and from 1000 to $10 \mathrm{hPa}$. Data are weighted by the square root of the cosine of the latitude, as well as by the square root of the pressure interval represented by that level (Thompson and Wallace, 2000). The wind fields are then regressed upon the resulting standardized leading principal component (PC) time series.

The changes in zonal wind and mean meridional circulation closely resembles the NAM (and to a lesser extent, the SAM) pattern, which suggests the response may involve 

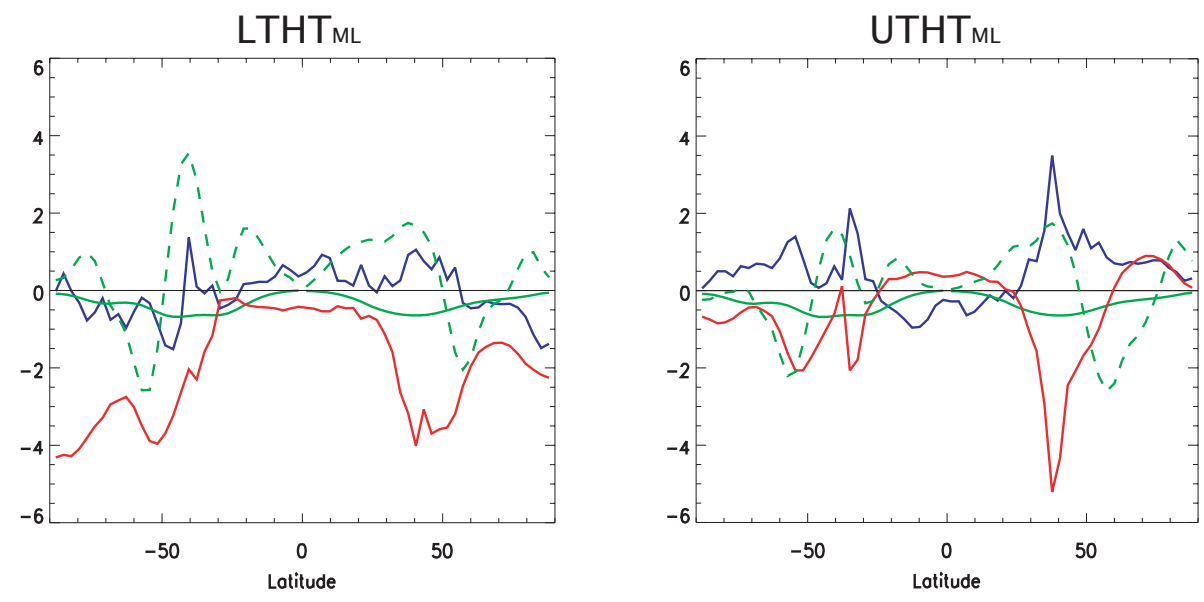

LTHT2XHL
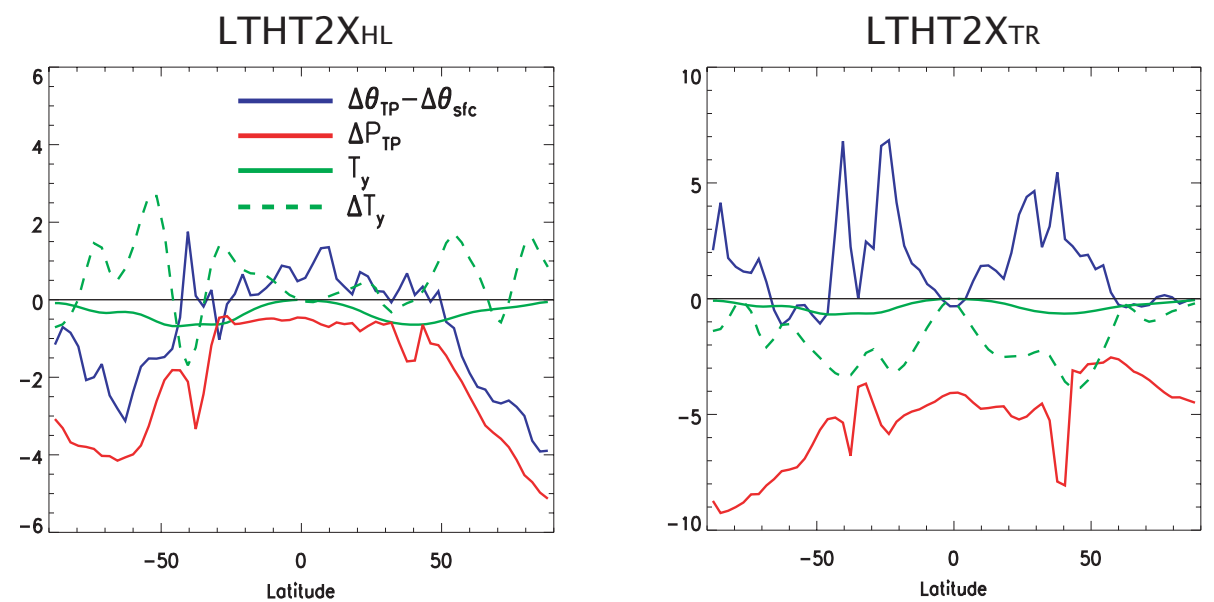

Fig. 8. Annual mean gross dry static stability change (blue; $\Delta \theta_{\mathrm{TP}}-\Delta \theta_{\mathrm{sfc}}$ ), tropopause pressure change (red; $\Delta P_{\mathrm{TP}}$ ), climatological baroclinicity at $500 \mathrm{hPa}$ (green solid; $T_{y}$ ) and the corresponding response (green dashed; $\Delta T_{y}$ ) for (top left) $\mathrm{LTHT}_{\mathrm{ML}}$, (top right) $\mathrm{UTHT}_{\mathrm{ML}}$, (bottom left) LTHT2 $\mathrm{x}_{\mathrm{HL}}$ and (bottom right) LTHT2x $\mathrm{x}_{\mathrm{TR}}$. Units are $\mathrm{K}, \mathrm{hPa}, \mathrm{K} \mathrm{km}^{-1} 10^{-4}$ and $\mathrm{K} \mathrm{km}^{-1} 10^{-2}$, respectively.

wave mean-flow interaction and downward control theory (Haynes et al., 1991; Baldwin and Dunkerton, 1999). The MAM $10 \mathrm{PLO} 3_{\mathrm{HL}}$ response also features an anomalous tropospheric meridional circulation, with rising motion poleward of $60^{\circ}$, sinking motion between $30-60^{\circ}$, and equatorward flow in the upper troposphere, somewhat like an intensified Ferrel Cell, but stretched poleward. This thermally indirect circulation coincides with warming near its sinking branch (near $45^{\circ}$ ), and cooling in the rising branch $\left(\right.$ near $70^{\circ}$ ). Imposition of these temperature anomalies on the background state produces a poleward displacement of the maximum tropospheric $T_{y}$, consistent with the tropospheric zonal wind anomaly near $60^{\circ}$. Figure 9 suggests that this anomalous residual circulation - particularly in the $\mathrm{NH}-$ is balanced by a poleward shift of eddy westerly momentum flux convergence near $60^{\circ}$, which sustains the westerly wind anomaly. The response is also associated with an increase in downward, equatorward wave energy and EP-flux divergence in the mid-latitude stratosphere and troposphere.
We find that our analysis of the NH spring-time response also approximately holds for the SH (not shown). For example, each stratospheric cooling experiment features an increase in SH SON wave refraction: $23 \%, 21 \%, 32 \%$ and $2 \%$ for $10 \mathrm{PLO} 3,10 \mathrm{PLO}_{\mathrm{HL}}, 10 \mathrm{PLO} 3_{\mathrm{ML}}$ and $10 \mathrm{PLO} 3_{\mathrm{TR}}$, respectively.

For $2 \times \mathrm{CO} 2$ and LTHT, Table 4 shows NH tropical expansion primarily occurs during two seasons: MAM and DJF. Similar to the stratospheric cooling experiment, both LTHT and $2 \times \mathrm{CO} 2$ feature a NAM-like $U$ response and meridional circulation response pattern, which is associated with a wavemodulated stratospheric pathway (not shown). Both signals feature an increase in wave refraction (Table 6), which is associated with an increase in downward, equatorward wave energy and EP-flux divergence in the mid-latitude stratosphere and troposphere. An anomalous meridional circulation in the troposphere and a poleward shift of eddy westerly momentum flux convergence near $60^{\circ} \mathrm{N}$, also occurs. Similarly, CMIP3 $2 \times \mathrm{CO} 2$ also features an increase in NH MAM 

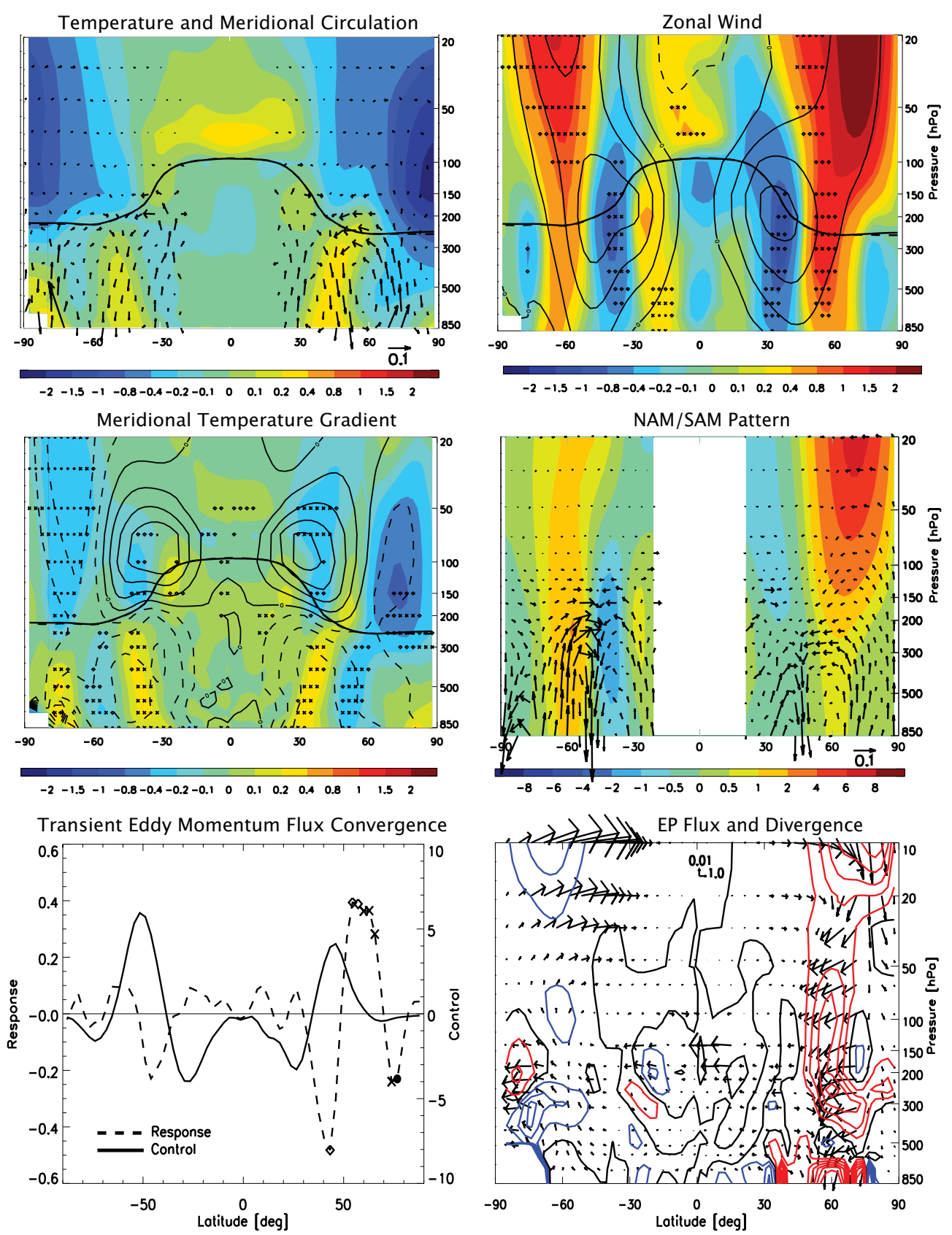

Fig. 9. MAM $10 \mathrm{PLO}_{\mathrm{HL}}$ response of (top left) temperature and meridional circulation, (top right) zonal wind, (middle left) meridional temperature gradient, (middle right) SAM/NAM $U$ pattern, (bottom left) $250 \mathrm{hPa}$ transient eddy momentum flux convergence [K m s${ }^{-1}$ ] and (bottom right) EP flux $\left[\mathrm{m}^{2} \mathrm{~s}^{-2}\right]$ and flux divergence $\left[10^{-6} \mathrm{~m} \mathrm{~s}^{-2}\right]$, divided by the standard density. $\mathrm{T}_{y}(U)$ contour interval is $2 \times 10^{-3} \mathrm{~K}$ $\mathrm{km}^{-1}\left(10 \mathrm{~m} \mathrm{~s}^{-1}\right)$ with negative values dashed. Units of NAM/SAM are $\mathrm{m} \mathrm{s}^{-1}$ per standard deviation of the PC time series. Indicated vector length (top left) represents $0.1 \mathrm{~cm} \mathrm{~s}^{-1}$ for the meridional component and $-0.1 \times 10^{-4} \mathrm{~Pa} \mathrm{~s}^{-1}$ for the vertical component. EP flux divergence contour interval is $[-6,-5,-4,-3,-2,-1,0,1,2,3,4,5,6]$, with negative values blue and positive values red. Symbols represent significance as in Fig. 2. Transient eddy momentum flux, $\overline{u^{\prime} v^{\prime}}$ is estimated according to $\overline{u v}-\bar{u} \bar{v}$, where primes denote zonal deviations and overbars indicate zonal averages.

and DJF wave refraction of $15 \%$ and $13 \%$, respectively (Table 6). Moreover, a significant, but weak, relationship exists between CMIP3 $2 \times \mathrm{CO} 2 \mathrm{NH}$ wave refraction and jet displacement for both DJF and MAM, with correlations of 0.44 and 0.43 , respectively. This suggests that a wave-modulated stratospheric pathway may play an important role in warming induced tropical expansion, particularly in the $\mathrm{NH}$ during MAM and DJF, regardless of the cause of the warming. 
Table 6. Northern Hemisphere 850-20 hPa percent change in wave refraction for the (top) stratospheric cooling experiments and (bottom) global warming experiments. Also included is the midlatitude, lower tropospheric heating experiments LTHT $_{M L}$ and LTHT2 $x_{M L}$ ), as well as the ensemble mean CMIP3 $2 \times \mathrm{CO} 2$ wave refraction. Wave refraction is estimated as the meridional component of EP flux divided by the vertical component. A more positive value indicates more equatorward wave propagation.

\begin{tabular}{|c|c|c|c|c|}
\hline Signal & DJF & MAM & JJA & SON \\
\hline 10PLO3 & 2 & 15 & -26 & 5 \\
\hline $10 \mathrm{PLO}^{\mathrm{HL}}$ & 1 & 35 & -25 & -8 \\
\hline $10 \mathrm{PLO} 3 \mathrm{ML}$ & 21 & 25 & -8 & -2 \\
\hline $10 \mathrm{PLO} 3 \mathrm{TR}$ & 5 & 20 & -29 & -8 \\
\hline LTHT & 19 & 21 & -25 & -3 \\
\hline LTHT2x & 23 & 38 & -22 & -7 \\
\hline LTHT4x & 26 & -32 & -31 & -17 \\
\hline $2 \times \mathrm{CO} 2$ & 33 & 56 & -12 & 4 \\
\hline $8 \times \mathrm{CO} 2$ & 49 & 49 & 38 & 15 \\
\hline $\mathrm{LTHT}_{\mathrm{ML}}$ & 3 & 8 & -13 & -8 \\
\hline LTHT2x $x_{M L}$ & 39 & 12 & -16 & 2 \\
\hline $2 \times \mathrm{CO} 2$ CMIP3 & 13 & 15 & -13 & 24 \\
\hline
\end{tabular}

We also note that similar behavior occurs for the mid-latitude lower-tropospheric heating experiments. Both LTHT $_{M L}$ and LTHT2 $x_{M L}$ feature an increase in MAM downward, equatorward wave energy (increase in wave refraction, Table 6) and EP-flux divergence, as well as cooling of the polar stratosphere, a decrease in polar stratospheric geopotential heights and a decrease in high-latitude surface pressure (not shown). This is analogous (but opposite) to the negative NAM response to anomalous Eurasian snow cover (e.g., Cohen et al., 2007; Fletcher et al., 2009; Allen and Zender, 2010).

\subsection{Tropospheric pathway}

Figure 10 shows a scatterplot of the tropospheric (850$300 \mathrm{hPa}$ ) jet displacement versus the difference in midand high-latitude warming amplification for the 5 global warming experiments (LTHT, LTHT2x, LTHT4x, $2 \times \mathrm{CO} 2$ and $8 \times \mathrm{CO} 2)$ and 6 latitude-restricted heating experiments $\left(\mathrm{LTHT}_{\mathrm{TR}}, \mathrm{LTHT}_{\mathrm{ML}}, \mathrm{LTHT}_{\mathrm{HL}}, \mathrm{LTHT}_{2} \mathrm{x}_{\mathrm{TR}}, \mathrm{LTHT} 2 \mathrm{x}_{\mathrm{ML}}\right.$, LTHT $\left.2 x_{\mathrm{HL}}\right)$. Warming amplification of mid-latitudes $\left(\mathrm{AMP}_{\mathrm{ML}}\right)$ is defined as the log-pressure area weighted temperature (i.e., thickness) response between $30-60^{\circ}$ minus that between $0-30^{\circ}$. For high-latitudes $\left(\mathrm{AMP}_{\mathrm{HL}}\right)$, the log-pressure area weighted temperature response between $60-90^{\circ}$ is differenced with that between $30-60^{\circ}$. Table 7 lists the amplification factors. This choice of this metric was inspired by the responses found in the latitude-restricted tropospheric heating experiments. When high-latitudes warm relative to mid-latitudes, $\mathrm{AMP}_{\mathrm{HL}}$ is positive, and we expect equatorward jet displacement. When
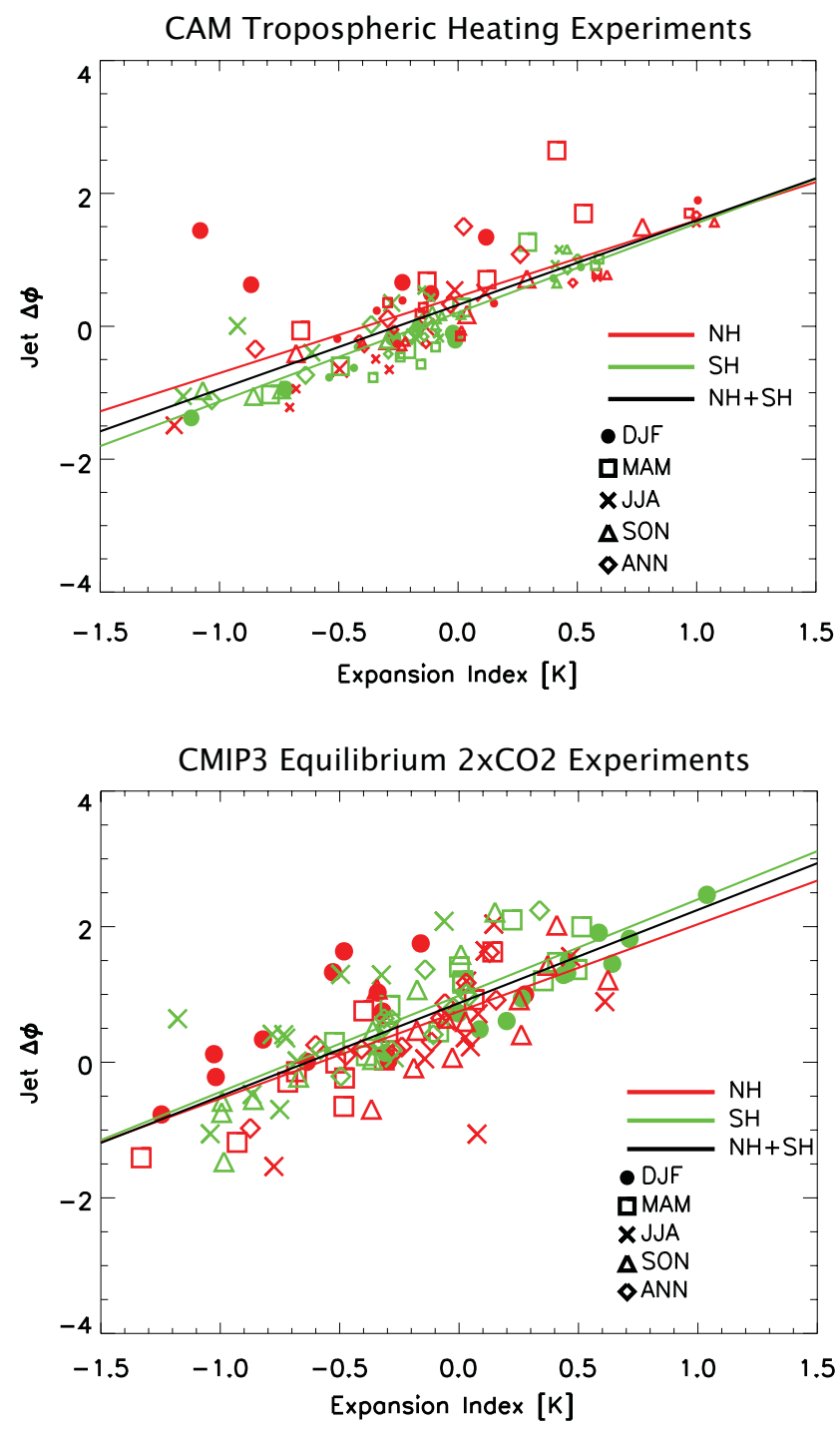

Fig. 10. Scatterplot of tropospheric poleward jet displacement versus the expansion index for the (top panel) CAM tropospheric heating experiments and (bottom panel) 12 CMIP3 $2 \times \mathrm{CO} 2$ equilibrium experiments. CAM tropospheric heating experiments include the 5 global warming experiments (larger symbols; LTHT, LTHT2x, LTHT4x, $2 \times \mathrm{CO} 2,8 \times \mathrm{CO} 2)$ and 6 latitude-restricted heating experiments (smaller symbols; $\mathrm{LTHT}_{\mathrm{TR}}, \mathrm{LTHT}_{\mathrm{ML}}, \mathrm{LTHT}_{\mathrm{HL}}$, LTHT2 $x_{\text {TR }}$, LTHT2 $x_{\text {ML }}$, LTHT2 $x_{\text {HL }}$ ). Also included are the corresponding linear regression lines, all of which are significant at the $99 \%$ confidence level.

the mid-latitudes warm relative to low-latitudes, $\mathrm{AMP}_{\mathrm{ML}}$ is positive, and we expect poleward jet displacement. Taking the difference, $\mathrm{AMP}_{\mathrm{ML}}-\mathrm{AMP}_{\mathrm{HL}}$, results in a quantity that accounts for these two competing effects. As the difference becomes more positive/less negative, then mid-latitude warming amplification dominates, and we expect more tropical expansion/less contraction; vice versa as $\mathrm{AMP}_{\mathrm{ML}}-\mathrm{AMP}_{\mathrm{HL}}$ becomes less positive/more negative. We call this quantity the "Expansion Index" (EI). Based on 
Table 7. Tropospheric (850-300 hPa) warming amplification factors for high-latitudes (HL; 60-90 minus 30-60 $)$ and mid-latitudes (ML; $30-60^{\circ}$ minus $0-30^{\circ}$ ) for the global warming experiments. Factors are based on log-pressure and area weighting. Also included are the corresponding values based on the ensemble mean of 12 CMIP3 $2 \times \mathrm{CO} 2$ experiments. Units are K.

\begin{tabular}{|c|c|c|c|c|c|c|c|c|c|c|c|}
\hline \multirow[t]{2}{*}{ Signal } & & \multicolumn{2}{|c|}{ ANN } & \multicolumn{2}{|c|}{ DJF } & \multicolumn{2}{|c|}{ MAM } & \multicolumn{2}{|c|}{ JJA } & \multicolumn{2}{|c|}{ SON } \\
\hline & & HL & ML & HL & ML & $\mathrm{HL}$ & ML & $\mathrm{HL}$ & ML & $\mathrm{HL}$ & ML \\
\hline \multirow{2}{*}{ LTHT } & $\mathrm{NH}$ & 0.02 & -0.01 & -0.01 & -0.13 & -0.14 & -0.02 & 0.22 & 0.08 & -0.02 & 0.02 \\
\hline & $\mathrm{SH}$ & 0.22 & 0.03 & 0.24 & -0.04 & 0.27 & 0.05 & 0.23 & 0.05 & 0.16 & 0.05 \\
\hline \multirow{2}{*}{ LTHT2x } & $\mathrm{NH}$ & 0.16 & -0.13 & -0.06 & -0.29 & 0.01 & -0.12 & 0.41 & -0.08 & 0.24 & -0.04 \\
\hline & SH & 0.62 & -0.02 & 0.62 & -0.11 & 0.56 & 0.07 & 0.63 & 0.02 & 0.67 & -0.07 \\
\hline \multirow{2}{*}{ LTHT4x } & $\mathrm{NH}$ & 0.64 & -0.21 & 0.40 & -0.47 & 0.35 & -0.30 & 1.15 & -0.03 & 0.66 & -0.02 \\
\hline & $\mathrm{SH}$ & 1.02 & -0.01 & 0.94 & -0.17 & 0.93 & 0.15 & 1.18 & 0.03 & 1.03 & -0.03 \\
\hline \multirow{2}{*}{$2 \times \mathrm{CO} 2$} & $\mathrm{NH}$ & -0.05 & 0.21 & -0.15 & -0.03 & -0.37 & 0.16 & 0.24 & 0.35 & 0.07 & 0.36 \\
\hline & SH & 0.36 & 0.22 & 0.29 & 0.27 & 0.30 & 0.31 & 0.45 & 0.17 & 0.43 & 0.13 \\
\hline \multirow{2}{*}{$8 \times \mathrm{CO} 2$} & $\mathrm{NH}$ & 1.08 & 1.10 & 1.04 & -0.03 & 0.10 & 0.52 & 2.11 & 2.10 & 1.05 & 1.82 \\
\hline & SH & 0.95 & 0.59 & 0.63 & 0.61 & 0.70 & 1.00 & 1.35 & 0.43 & 1.15 & 0.29 \\
\hline \multirow{2}{*}{$2 \times \mathrm{CO} 2 \mathrm{CMIP} 3$} & $\mathrm{NH}$ & 0.03 & -0.40 & 0.14 & -0.40 & 0.10 & -0.39 & -0.07 & -0.02 & -0.05 & 0.02 \\
\hline & SH & -0.23 & -0.41 & -0.59 & -0.21 & -0.35 & -0.29 & 0.10 & -0.56 & -0.08 & -0.57 \\
\hline
\end{tabular}

the 6 latitude-restricted heating experiments in Fig. 10, EI accounts for $86 \%$ of the $\mathrm{NH}$ and $\mathrm{SH}$ jet displacements. For the annual mean only, EI accounts for $94 \%$ of the $\mathrm{NH}$ and $\mathrm{SH}$ jet displacements. We note that EI can be rewritten as the difference between twice the mid-latitude warming and the sum of low- and high-latitude warming (a rough Laplacian): $2 \times \Delta T_{30-60}-\left(\Delta T_{0-30}+\Delta T_{60-90}\right)$.

The global warming experiments are generally consistent with this notion. Over all five experiments and seasons, the relationship is significant at the $99 \%$ confidence level for $\mathrm{NH}, \mathrm{SH}$ and both hemispheres, accounting for $42 \%, 72 \%$ and $55 \%$ of the jet displacement, respectively. For the annual mean only, the expansion index accounts for $76 \%$ of the $\mathrm{NH}$ and $\mathrm{SH}$ jet displacement. The dominant response in these experiments - equatorward $\mathrm{SH}$ jet displacement - is consistent with the large $\mathrm{SH}$ high-latitude warming, and large $\mathrm{AMP}_{\mathrm{HL}}$. The diagnostic also explains the increased equatorward displacement when the heating rate is increased in the LTHT experiments. Increasing the heating rate generally results in amplified high-latitude warming, which is associated with equatoward jet displacement. Table 7 shows that the annual mean $\mathrm{SH} \mathrm{AMP}_{\mathrm{HL}}$ increases from 0.22 to $1.02 \mathrm{~K}$ for LTHT to LTHT4x; and from 0.02 to $0.64 \mathrm{~K}$ in the NH. At the same time, however, $\mathrm{AMP}_{\mathrm{ML}}$ generally decreases, particularly in the $\mathrm{NH}$. Furthermore, $\mathrm{AMP}_{\mathrm{HL}}$ is generally largest in the $\mathrm{SH}$, relative to the $\mathrm{NH}$, consistent with equatorward $\mathrm{SH}$ jet displacement in nearly all cases. The relationship is weakest in the NH for DJF and MAM, which may be related to the wave-modulated stratospheric pathway during these seasons. Without DJF and MAM, the expansion index accounts for $81 \%$ of the variation in NH jet displacement. Similar conclusions exist when the three mid-tropospheric global warming experiments (MTHT, MTHT2x and MTHT4x) are included in the analysis.

Figure 10 further supports the idea that part of the jet shift can be thought of as a geostrophic adjustment to an altered temperature profile - not only when certain latitude bands are heated, but also for global warming experiments like LTHT and $2 \times \mathrm{CO} 2$. Our experiments suggest that poleward jet displacement is partially driven by mid-latitude heating, while equatorward jet displacement is partially driven by highlatitude heating. However, a wave-modulated stratospheric pathway during the $\mathrm{NH}$ active seasons is also important, resulting in poleward $\mathrm{NH}$ jet displacement during MAM and DJF which projects onto the positive phase of the NAM. For LTHT this mechanism eventually weakens with increased heating (e.g., LTHT4x), where high-latitude amplification dominates and the maximum $T_{y}$ is displaced equatorward, resulting in equatorward displacement of the tropospheric jets.

Figure 10 also shows a similar relationship between the expansion index and jet displacement exist based on CMIP3 $2 \times \mathrm{CO} 2$ equilibrium experiments. Even though this metric does not directly account for the effects of $\mathrm{CO}_{2}$ induced stratospheric cooling, it accounts for $45 \%, 67 \%$ and $56 \%$ of the of the variation in jet displacement in the $\mathrm{NH}, \mathrm{SH}$ and both hemispheres, respectively. Based on the annual mean only, EI accounts for $76 \%$ of the $\mathrm{NH}$ and $\mathrm{SH}$ jet displacement. Similar results are obtained if jet displacements are based on others percentiles. Using the 70th-95th percentile in 5 percentile increments, EI accounts for $61 \%$ to $77 \%$ of the annual mean jet displacement; using the alternate, maximum $U$ method, $66 \%$ of the annual mean jet displacement is accounted for. This relationship is somewhat better than the relationship Lu et al. (2007) found between tropical 
expansion and tropopause height (stability); there, increases in extratropical $\left(35-55^{\circ}\right)$ tropopause height accounted for $66 \%$ of the variation in annual mean MMC expansion using CMIP3 A2 experiments. More recently, Lu et al. (2008) found a significant relationship between poleward MMC displacement and a decrease in Philips criticality, the latter of which occurred primarily due to an increase in extratropical static stability. In the SH during DJF, Philips criticality accounted for $67 \%$ of the variation in MMC expansion. Similarly, the expansion index accounts for $92 \%$ of the jet displacement in the SH during DJF. We also find that it accounts for most of the DJF SH variation in other metrics of tropical expansion, including $P-E(81 \%)$ and MMC $(81 \%)$. Similar, but weaker, results exist for SH ANN, where the expansion index accounts for $45 \%$ and $46 \%$ of the variation in $P-E$ and MMC, respectively. Thus, the expansion index helps to explain not only dynamical measures of tropical expansion, but hydrological measures too, particularly in the $\mathrm{SH}$.

We also estimated the relationship between the expansion index and tropospheric jet displacement using the 10 $1 \%$ to $4 \times \mathrm{CO} 2 \mathrm{CMIP} 3$ experiments, and with five reanalyses, including NCEP/NCAR (Kalnay et al., 1996), NCEPDOE (Kanamitsu et al., 2002), MERRA (Rienecker et al., 2011), ERA40 (Uppala et al., 2005) and ERA-Interim (Dee et al., 2011). The first three reanalyses are analyzed from 1979-2010; ERA40 from 1979-2002 and ERA-Interim from 1989-2010. Based on the annual mean, the expansion index accounts for $70 \%$ of the variance in $\mathrm{NH}$ and $\mathrm{SH}$ jet displacements in $4 \times \mathrm{CO} 2 \mathrm{CMIP} 3$ experiments; and $55 \%$ of the corresponding jet displacements in reanalyses.

We conclude by comparing the CAM global warming experiments with the CMIP3 $2 \times \mathrm{CO} 2$ experiments. Similar to the CAM experiments, the EI-jet displacement relationship is weakest in the NH during DJF, where it accounts for only $46 \%$ of the variation in jet displacement. We also note that the NH MAM CAM $2 \times \mathrm{CO} 2$ jet displacement is much larger than the CMIP3 ensemble $\left(1.70^{\circ}\right.$ versus $\left.-0.01^{\circ}\right)$, which is consistent with more MAM wave refraction in CAM $2 \times \mathrm{CO} 2$ (56\% versus the CMIP3 ensemble mean of $15 \%$ ). CAM $2 \times \mathrm{CO} 2$ also features less SH jet displacement than CMIP3 $\left(0.09^{\circ}\right.$ versus $0.73^{\circ}$ for the annual mean $)$, despite a similar expansion index ( -0.14 versus -0.18 for CMIP3). Although the reasons are not clear, the other metrics of CAM $2 \times \mathrm{CO} 2$ tropical width both show greater $\mathrm{SH}$ displacement $\left(0.60^{\circ}\right.$ for $P-E$ and $0.42^{\circ}$ for MMC). In addition to these equilibrium experiments, we have also conducted transient $\mathrm{CO}_{2} \mathrm{CAM}$ experiments over the latter half of the 20th century using several ensembles (not shown) and obtain similar minimal $\mathrm{SH}$ jet displacement. This suggests CAM3 is less sensitive to $\mathrm{CO}_{2}$-induced $\mathrm{SH}$ poleward jet displacement, relative to other CMIP3 models.

\section{Conclusions}

The CAM3 general circulation model is used to investigate how tropical width responds to idealized thermal perturbations, focusing on zonal displacement of the tropospheric jets. The heat sources include global and zonally restricted lower-tropospheric warmings and stratospheric coolings, which coarsely represent possible impacts of ozone or aerosol changes. Our results show that global stratospheric cooling, as well as stratospheric cooling of the high- and midlatitudes, yields poleward jet displacement. This response is related to wave-mean flow interaction and involves an increase in wave refraction, and downward propagation of the stratospheric wind anomaly. This response is in general agreement with similar studies using idealized models (e.g., Haigh et al., 2005) and supports the recent findings of Polvani et al. (2011), who showed stratospheric ozone loss is the main driver of twentieth century atmospheric circulation changes in the Southern Hemisphere (SH).

CAM3 tropospheric heating experiments show that highlatitude heating results in equatorward jet displacement; midlatitude heating results in poleward jet displacement; and low-latitude heating yields negligible jet displacement (but a significant increase in the strength of the tropical circulation). Similar results were obtained with the GFDL AM2.1. Although our high-latitude response is consistent with a recent study using a simplified GCM (Butler et al., 2010), our tropical heating results differ - Butler et al. (2010) found tropical heating forces a significant poleward shift of the extratropical storm tracks (and tropospheric jets). We note that the Butler et al. (2010) results appear to contradict the El Ninõ response, which is associated with tropical tropospheric warming and equatorward displacement of the jets (Lu et al., 2008). Reasons for this discrepancy are unclear, but may be related to the meridional extent of the forcing and subsequent temperature response. The tropical heating in Butler et al. (2010) extends all the way to $45^{\circ} \mathrm{N} / \mathrm{S}$, whereas our $\mathrm{LTHT}_{\mathrm{TR}}$ heating extends to $30^{\circ} \mathrm{N} / \mathrm{S}$. As noted in Butler et al. (2010), the projection of this heating into the mid-latitudes may play a significant role in the jet shift. Perhaps a more appropriate comparison to their tropical heating experiment is our $\mathrm{LTHT}_{\mathrm{TRML}}$ experiment, where heat is added from $0-60^{\circ} \mathrm{N} / \mathrm{S}$. Similar to the Butler et al. (2010) result, LTHT $_{\text {TRML yields mid-latitude }}$ warming and poleward jet displacement. Additional possibilities for the discrepancy are the existence of topography in our model, which is important for the wave-modulated stratospheric pathway; and moisture/convective processes which could change the way heat is distributed.

Globally uniform lower tropospheric heating (LTHT) and $2 \times \mathrm{CO} 2$ yield similar tropical width responses. Both yield negligible jet displacement in the $\mathrm{SH}$ and poleward jet displacement in the NH, particularly during DJF and MAM. Similar to the stratospheric cooling experiments, the boreal winter/spring expansion is related to a wave-modulated stratospheric pathway and a positive NAM-like response. 
This result is consistent with Previdi and Liepert (2007), who showed $50 \%$ of the subtropical dry zone expansion can be explained by positive trends in the annular modes. Other metrics of tropical displacement, including $P-E$ and $\mathrm{MMC}$, generally yield a similar response. However, there are some differences that warrant further study.

Jet shifts associated with the tropospheric heating experiments are related to zonal displacements of the maximum meridional tropospheric temperature gradient. Heating the mid-latitudes results in maximum mid-latitude warming, consistent with a down gradient eddy heat flux response (i.e., oriented away from the latitude of maximum heating). This weakens the tropospheric meridional temperature gradient $\left(T_{y}\right)$ on the equatorward flank of the $T_{y}$ maximum and strengthens $T_{y}$ on the poleward flank of the maximum. The jet responds by moving poleward, consistent with a geostrophic adjustment to the altered meridional temperature gradient, in accord with thermal wind balance. The opposite occurs when heat is added to the high-latitudes. This relationship also exists for global warming experiments, including LTHT and $2 \times \mathrm{CO} 2$.

Some of our experiments are inconsistent with previously proposed mechanisms of tropical expansion (e.g., Lorenz and DeWeaver, 2007; Frierson et al., 2007; Lu et al., 2007). For example, heating the tropical troposphere results in a global increase in tropopause height, yet negligible poleward tropical displacement. Our experiments highlight the importance of altered tropospheric temperature gradients and a wavemodulated stratospheric pathway. For the global warming experiments, the "Expansion Index", which quantifies the difference between mid-latitude and high-latitude warming amplification, accounts for over half of the tropospheric jet displacements; this increases to over $70 \%$ for annual mean jet displacements. A similar relationship also exists for $2 \times \mathrm{CO} 2$ CMIP3 equilibrium experiments and $1 \%$ to $4 \times \mathrm{CO} 2 \mathrm{CMIP} 3$ transient experiments. Five reanalyses also show the relationship exists for recent climate trends.

This study has important implications for heterogeneous warming agents, such as tropospheric ozone and absorbing aerosols, as briefly discussed by Allen and Sherwood (2011). Such non- $\mathrm{CO}_{2}$ forcings - particularly those that warm the mid-latitudes and are underestimated by most models (e.g., Ramanathan and Carmichael, 2008; Koch et al., 2009) may help explain the discrepancy between modeled and observed estimates of recent tropical expansion. Moreover, a recent study by Scaife et al. (2012) found increased $\mathrm{CO}_{2}$ in GCMs with a well-resolved stratosphere yielded an equatorward storm track shift, particularly over the Atlantic during winter. This implies the observed poleward shift may be due more to heterogeneous warming agents, as opposed to greenhouse gases. We are currently investigating the importance of non- $\mathrm{CO}_{2}$ forcings in recent tropical expansion.
Acknowledgements. This study was funded by RJA's UCR initial complement, SIO NOAA grant NA10OAR43210141, and by NSF ARC-0714088 and NASA NNX07AR23G, UC Irvine. We acknowledge the modeling groups, the Program for Climate Model Diagnosis and Intercomparison (PCMDI) and the WCRP's Working Group on Coupled Modelling (WGCM) for their roles in making available the WCRP CMIP3 multi-model dataset. Support of this dataset is provided by the Office of Science, US Department of Energy. We thank Amy Butler, and one anonymous reviewer, for their helpful comments.

Edited by: T. J. Dunkerton

\section{References}

Allen, R. J. and Sherwood, S. C.: The impact of natural versus anthropogenic aerosols on atmospheric circulation in the Community Atmosphere Model, Climate Dyn., 36, 1959-1978, doi:10.1007/s00382-010-0898-8, 2011.

Allen, R. J. and Zender, C. S.: The effects of continental-scale snow albedo anomalies on the wintertime Arctic Oscillation, J. Geophys. Res., 115, D23105, doi:10.1029/2010JD014490, 2010.

Anderson, J., Balaji, V., Broccoli, A., Cooke, W., Delworth, T., Dixon, K., Donner, L., Dunne, K., Freidenreich, S., Garner, S., Gudgel, R., Gordon, C., Held, I., Hemler, R., Horowitz, L., Klein, S., Knutson, T., Kushner, P., Langenhost, A., Lau, N., Liang, Z., Malyshev, S., Milly, P., Nath, M., Ploshay, J., Ramaswamy, V., Schwarzkopf, M., Shevliakova, E., Sirutis, J., Soden, B., Stern, W., Thompson, L., Wilson, R., Wittenberg, A., Wyman, B., and GFDL Global Atmospheric Model Dev: The new GFDL global atmosphere and land model AM2-LM2: Evaluation with prescribed SST simulations, J. Climate, 17, 4641-4673, 2004.

Baldwin, M. P. and Dunkerton, T. J.: Propagation of the Arctic Oscillation from the stratosphere to the troposphere, J. Geophys. Res., 104, 30937-30946, 1999.

Bond, T. C., Bhardwaj, E., Dong, R., Jogani, R., Jung, S., Roden, C., Streets, D. G., and Trautmann, N. M.: Historical emissions of black and organic carbon aerosol from energy related combustion, 1850-2000, Global Biogeochem. Cy., 21, GB2018, doi:10.1029/2006GB002840, 2007.

Brayshaw, D. J., Hoskins, B., and Blackburn, M.: The storm-track response to idealized SST perturbations in an aquaplanet GCM, J. Atmos. Sci., 65, 2842-2860, 2008.

Butler, A. H., Thompson, D. W. J., and Heikes, R.: The steady-state atmospheric circulation response to climate change-like thermal forcings in a simple general circulation model, J. Climate, 23, 3474-3496, 2010.

Butler, A. H., Thompson, D. W. J., and Birner, T.: Isentropic slopes, downgradient eddy fluxes, and the extratropical atmospheric circulation response to tropical tropospheric heating, J. Atmos. Sci., 68, 2292-2305, 2011.

Chen, G. and Held, I.: Phase speed spectra and the recent poleward shift of the Southern Hemisphere surface westerlies, Geophys. Res. Lett., 34, L21805, doi:10.1029/2007GL031200, 2007.

Chen, G., Lu, J., and Frierson, D. W.: Phase speed spectra and the latitude of surface westerlies: Interannual variability and global warming trend, J. Climate, 21, 5942-5959, 2008.

Chen, G., Plumb, R. A., and Lu, J.: Sensitivities of zonal mean atmospheric circulation to SST warming in an aqua-planet model, 
Geophys. Res. Lett., 37, L12701, doi:10.1029/2010GL043473, 2010.

Chung, C. E., Ramanathan, V., Kim, D., and Podgorny, I. A.: Global anthropogenic aerosol direct forcing derived from satellite and ground-based observations, J. Geophys. Res., 110, D24207, doi:10.1029/2005JD006356, 2005.

Cohen, J., Barlow, M., Kushner, P. J., and Saito, K.: Stratospheretroposphere coupling and links with Eurasian land surface variability, J. Climate, 20, 5335-5343, 2007.

Collins, W. D., Rasch, P. J., Boville, B. A., Hack, J. J., McCaa, J. R., Williamson, D. L., Kiehl, J. T., Briegleb, B., Bitz, C., Lin, S.-J., Zhang, M., and Dai, Y.: Description of the NCAR Community Atmosphere Model (CAM 3.0). Technical Report NCAR/TN464+STR, National Center for Atmospheric Research, Boulder, CO, 226 pp., 2004.

Dee, D. P., Uppala, S. M., Simmons, A. J., Berrisford, P., Poli, P., Kobayashi, S., Andrae, U., Balmaseda, M. A., Balsamo, G., Bauer, P., Bechtold, P., Beljaars, A. C. M., van de Berg, L., Bidlot, J., Bormann, N., Delsol, C., Dragani, R., Fuentes, M., Geer, A. J., Haimberger, L., Healy, S. B., Hersbach, H., Hólm, E. V., Isaksen, L., Kållberg, P., Köhler, M., Matricardi, M., McNally, A. P., Monge-Sanz, B. M., Morcrette, J.-J., Park, B.-K., Peubey, C., de Rosnay, P., Tavolato, C., Thépaut, J.-N., and Vitart, F.: The ERA-Interim reanalysis: Configuration and performance of the data assimilation system, Q. J. Roy. Meteorol. Soc., 137, 553597, 2011

Fletcher, C. G. and Kushner, P. J.: The role of linear interference in the Annular Mode response to Tropical SST forcing, J. Climate, 24, 778-794, doi:10.1175/2010JCLI3735.1, 2011.

Fletcher, C. G., Hardiman, S. C., Kushner, P. J., and Cohen, J.: The dynamical response to snow cover perturbations in a large ensemble of atmospheric GCM integrations, J. Climate, 22, 12081222, 2009.

Frierson, D. M. W., Lu, J., and Chen, G.: Width of the Hadley cell in simple and comprehensive general circulation models, Geophys. Res. Lett., 34, L18804, doi:10.1029/2007GL031115, 2007.

$\mathrm{Fu}, \mathrm{Q}$. and Lin, P.: Poleward shift of subtropical jets inferred from satellite-observed lower stratospheric temperatures, J. Climate, doi:10.1175/JCLI-D-11-00027.1, 2011.

Fu, Q., Johanson, C. M., Wallace, J. M., and Reichler, T.: Enhanced mid-latitude tropospheric warming in satellite measurements, Science, 312, 1179, doi:10.1126/science.1125566, 2006.

Gallego, D., Ribera, P., Garcia-Herrera, R., Hernandez, E., and Gimeno, L.: A new look for the Southern Hemisphere jet stream, Climate Dyn., 24, 607-621, 2005.

Haigh, J. D., Blackburn, M., and Day, R.: The response of tropopsheric circulation to perturbations in lower-stratospheric temperature, J. Climate, 18, 3672-3685, 2005.

Haynes, P. H., Marks, C. J., McIntyre, M. E., Shepherd, T. G., and Shine, K. P.: On the "downward control" of extratropical diabatic circulations by eddy-induced mean zonal forces, J. Atmos. Sci., 48, 651-678, 1991.

Held, I. M.: The general circulation of the atmosphere, paper presented at 2000 Woods Hole Oceanographic Institute Geophysical Fluid Dynamics Program, Woods Hole Oceanographic Institute, Woods Hole, Mass, available at: http://www.whoi.edu/page.do? pid=13076, 2000.

Held, I. M. and Soden, B. J.: Robust responses of the hydrological cycle to global warming, J. Climate, 19, 5686-5699, 2006.
$\mathrm{Hu}$, Y. and $\mathrm{Fu}, \mathrm{Q} .:$ Observed poleward expansion of the Hadley circulation since 1979, Atmos. Chem. Phys., 7, 5229-5236, doi:10.5194/acp-7-5229-2007, 2007.

Hudson, R. D., Andrade, M. F., Follette, M. B., and Frolov, A. D.: The total ozone field separated into meteorological regimes Part II: Northern Hemisphere mid-latitude total ozone trends, Atmos. Chem. Phys., 6, 5183-5191, doi:10.5194/acp-6-5183-2006, 2006.

Johanson, C. M. and Fu, Q.: Hadley cell widening: Model simulations versus observations, J. Climate, 22, 2713-2725, 2009.

Kalnay, E., Kanamitsu, M., Kistler, R., Collins, W., Deaven, D., Gandin, L., Iredell, M., Saha, S., White, G., Woollen, J., Zhu, Y., Leetmaa, A., Reynolds, B., Chelliah, M., Ebisuzaki, W., Higgins, W., Janowiak, J., Mo, K. C., Ropelewski, C., Wang, J., Jenne, R., and Hoseph, D.: The NCEP/NCAR 40-year reanalysis project, B. Am. Meteorol. Soc., 77, 437-471, 1996.

Kanamitsu, M., Ebisuzaki, W., Woollen, J., Yang, S.-K., Hnilo, J. J., Fiorino, M., and Potter, G. L.: NCEP-DOE AMIP-II Reanalysis (R-2), B. Am. Meteorol. Soc., 83, 1631-1643, 2002.

Kidston, J. and Gerber, E. P.: Intermodel variability of the poleward shift of the austral jet stream in the CMIP3 integrations linked to biases in 20th century climatology, Geophys. Res. Lett., 37, L09708, doi:10.1029/2010GL042873, 2010.

Kidston, J., Dean, S. M., Renwick, J. A., and Vallis, G. K.: A robust increase in the eddy length scale in the simulation of future climates, Geophys. Res. Lett., 37, L03806, doi:10.1029/2009GL041615, 2010.

Kidston, J., Vallis, G. K., Dean, S. M., and Renwick, J. A.: Can the increase in the eddy length scale under global warming cause the poleward shift of the jet streams?, J. Climate, 24, 3764-3780, doi:10.1175/2010JCLI3738.1, 2011.

Koch, D., Schulz, M., Kinne, S., McNaughton, C., Spackman, J. R., Balkanski, Y., Bauer, S., Berntsen, T., Bond, T. C., Boucher, O., Chin, M., Clarke, A., De Luca, N., Dentener, F., Diehl, T., Dubovik, O., Easter, R., Fahey, D. W., Feichter, J., Fillmore, D., Freitag, S., Ghan, S., Ginoux, P., Gong, S., Horowitz, L., Iversen, T., Kirkevåg, A., Klimont, Z., Kondo, Y., Krol, M., Liu, X., Miller, R., Montanaro, V., Moteki, N., Myhre, G., Penner, J. E., Perlwitz, J., Pitari, G., Reddy, S., Sahu, L., Sakamoto, H., Schuster, G., Schwarz, J. P., Seland, Ø., Stier, P., Takegawa, N., Takemura, T., Textor, C., van Aardenne, J. A., and Zhao, Y.: Evaluation of black carbon estimations in global aerosol models, Atmos. Chem. Phys., 9, 9001-9026, doi:10.5194/acp-9-9001-2009, 2009.

Kushner, P. J. and Polvani, L. M.: Stratosphere-troposphere coupling in a relatively simple AGCM: The role of eddies, J. Climate, 17, 629-639, 2004.

Kushner, P. J., Held, I. M., and Delworth, T. L.: Southern Hemisphere atmospheric circulation response to global warming, J. Climate, 14, 2238-2249, 2001.

Lindzen, R. S. and Farrell, B.: A simple approximate result for the maximum growth rate of baroclinic instabilities, J. Atmos. Sci., 37, 1648-1654, 1980.

Lorenz, D. J. and DeWeaver, E. T.: Tropopause height and zonal wind response to global warming in the IPCC scenario integrations, J. Geophys. Res., 112, D10119, doi:10.1029/2006JD008087, 2007.

Lu, J., Vecchi, G. A., and Reichler, T.: Expansion of the Hadley cell under global warming, Geophys. Res. Lett., 34, L06805, 
doi:10.1029/2006GL028443, 2007.

Lu, J., Chen, G., and Frierson, D. M. W.: Response of the zonal mean atmospheric circulation to El Niño versus global warming, J. Climate, 21, 5835-5851, 2008.

$\mathrm{Lu}$, J., Deser, C., and Reichler, T.: Cause of the widening of the tropical belt since 1958, Geophys. Res. Lett., 36, L03803, doi:10.1029/2008GL036076, 2009.

Newchurch, M. J., Yang, E.-S., Cunnold, D. M., Reinsel, G. C., Zawodny, J. M., and Russell III, J. M.: Evidence for slowdown in stratospheric ozone loss: First stage of ozone recovery, J. Geophys. Res., 108, 4507, doi:10.1029/2003JD003471, 2003.

Oleson, K. W., Dai, Y., Bonan, G., Bosilovich, M., Dickinson, R., Dirmeyer, P., Hoffman, F., Houser, P., Levis, S., Niu, G.-Y., Thornton, P., Vertenstein, M., Yang, Z.-L., and Zeng, X.: Technical description of the Community Land Model (CLM). Technical Report NCAR/TN-461+STR, National Center for Atmospheric Research, Boulder, CO, 174 pp., 2004.

Polvani, L. M. and Kushner, P. J.: Tropospheric response to stratospheric perturbations in a relatively simple general circulation model, Geophys. Res. Lett., 29, 1114, doi:10.1029/2001GL014284, 2002.

Polvani, L. M., Waugh, D. W., Correa, G. J. P., and Son, S.-W.: Stratospheric ozone depletion: The main driver of twentiethcentury atmospheric circulation changes in the Southern Hemisphere, J. Climate, 24, 795-812, 2011.

Previdi, M. and Liepert, B. G.: Annular modes and Hadley cell expansion under global warming, Geophys. Res. Lett., 34, L22701, doi:10.1029/2007GL031243, 2007.

Ramanathan, V. and Carmichael, G.: Global and regional climate changes due to black carbon, Nature Geosci., 1, 221-227, 2008.

Reichler, T., Dameris, M., and Sausen, R.: Determining the tropopause height from gridded data, Geophys. Res. Lett., 30, 2042, doi:10.1029/2003GL018240, 2003.

Rienecker, M. M., Suarez, M. J., Gelaro, R., Todling, R., Bacmeister, J., Liu, E., Bosilovich, M. G., Schubert, S. D., Takacs, L., Kim, G.-K., Bloom, S., Chen, J., Collins, D., Conaty, A., da Silva, A., Gu, W., Joiner, J., Koster, R. D., Lucchesi, R., Molod, A., Owens, T., Pawson, S., Pegion, P., Redder, C. R., Reichle, R., Robertson, F. R., Ruddick, A. G., Sienkiewicz, M., and Woollen, J.: MERRA: NASA's Modern-Era Retrospective Analysis for Research and Applications, J. Climate, 24, 3624-3648, 2011.

Rind, D., Perlwitz, J., and Lonergan, P.: AO/NAO response to climate change: 1. Respective influences of stratospheric and tropospheric climate changes, J. Geophys. Res., 110, D12107, doi:10.1029/2004JD005103, 2005.

Scaife, A., Spangehl, T., Fereday, D., Cubasch, U., Langematz, U., Akiyoshi, H., Bekki, S., Braesicke, P., Butchart, N., Chipperfield, M., Gettelman, A., Hardiman, S., Michou, M., Rozanov, E., and Shepherd, T.: Climate change projections and stratosphere-troposphere interaction, Climate Dyn., 38, 20892097, doi:10.1007/s00382-011-1080-7, 2012.

Seidel, D. J. and Randel, W. J.: Recent widening of the tropical belt: Evidence from tropopause observations, J. Geophys. Res., 112, D20113, doi:10.1029/2007JD008861, 2007.
Seidel, D. J., Fu, Q., Randel, W. J., and Reichler, T. J.: Widening of the tropical belt in a changing climate, Nature Geosci., 1, 21-24, doi:10.1038/ngeo.2007.38, 2008.

Shindell, D. T., Schmidt, G. A., Miller, R. L., and Rind, D.: Northern Hemisphere winter climate response to greenhouse gas, ozone, solar, and volcanic forcing, J. Geophys. Res., 106, 7193 7210, 2001.

Shindell, D. T., Faluvegi, G., Lacis, A., Hansen, J., Ruedy, R., and Aguilar, E.: Role of tropospheric ozone increases in 20th-century climate change, J. Geophys. Res., 111, D08302, doi:10.1029/2005JD006348, 2006.

Smith, K. L., Fletcher, C. G., and Kushner, P. J.: The role of linear interference in the Annular Mode response to extratropical surface forcing, J. Climate, 23, 6036-6050, 2010.

Smith, S. J., van Aardenne, J., Klimont, Z., Andres, R. J., Volke, A., and Delgado Arias, S.: Anthropogenic sulfur dioxide emissions: 1850-2005, Atmos. Chem. Phys., 11, 1101-1116, doi:10.5194/acp-11-1101-2011, 2011.

Thompson, D. W. J. and Wallace, J. M.: Annular modes in the extratropical circulation. Part I: Month to month variability, J. Climate, 13, 1000-1016, 2000.

Uppala, S., Kallberg, P., Simmons, A., Andrae, U., Bechtold, V., Fiorino, M., Gibson, J., Haseler, J., Hernandez, A., Kelly, G., Li, X., Onogi, K., Saarinen, S., Sokka, N., Allan, R., Andersson, E., Arpe, K., Balmaseda, M., Beljaars, A., Van De Berg, L., Bidlot, J., Bormann, N., Caires, S., Chevallier, F., Dethof, A., Dragosavac, M., Fisher, M., Fuentes, M., Hagemann, S., Holm, E., Hoskins, B., Isaksen, L., Janssen, P., Jenne, R., McNally, A., Mahfouf, J., Morcrette, J., Rayner, N., Saunders, R., Simon, P., Sterl, A., Trenberth, K., Untch, A., Vasiljevic, D., Viterbo, P., and Woollen, J.: The ERA-40 re-analysis, Q. J. R. Meteorol. Soc., 131, 2961-3012, 2005.

van Aardenne, J. A., Dentener, F. J., Olivier, J. G. J., Goldewijk, C. G. M. K., and Lelieveld, J.: A 1 x 1 degree resolution dataset of historical anthropogenic trace gas emissions for the period 1890 1990, Global Biogeochem. Cy., 15, 909-928, 2001.

Wang, S., Gerber, E. P., and Polvani, L. M.: Abrupt circulation responses to tropical upper tropospheric warming in a relatively simple stratosphere-resolving AGCM, J. Climate, in press, 2012.

Wilks, D. S.: Statisitcal Methods in the Atmospheric Sciences, Academic Press, 467 pp., 1995

Williams, G. P.: Circulation sensitivity to tropopause height, J. Atmos. Sci., 63, 1954-1961, 2006.

Yin, J. H.: A consistent poleward shift of the strom tracks in simulations of 21st century climate, Geophys. Res. Lett., 32, L18701, doi:10.1029/2005GL023684, 2005.

Zhou, Y. P., Xu, K.-M., Sud, Y. C., and Betts, A. K.: Recent trends of the tropical hydrological cycle inferred from Global Precipitation Climatology Project and International Satellite Cloud Climatology Project data, J. Geophys. Res., 116, D09101, doi:10.1029/2010JD015197, 2011. 